\title{
The Political and Economic History of Vineyard Planting Rights in Europe: From Montesquieu to the European Union*
}

\author{
Giulia Meloni ${ }^{\mathrm{a}}$ and Johan Swinnen ${ }^{\mathrm{b}}$ \\ "Let us, therefore, lay down a certain maxim, that whenever the public good happens to be the \\ matter in question, it is not for the advantage of the public to deprive an individual of his \\ property, or even to retrench the least part of it by a law, or a political regulation."1
}

Montesquieu, 1748b, XXVI, XV, p.252

\begin{abstract}
In 2008, the EU voted to liberalize its system of planting rights which has strictly regulated vine plantings in the EU. However, after an intense lobbying campaign the liberalization of the planting right system was overturned in 2013 and new regulations could create an even more restrictive system. European wine associations have complained about the detrimental effects of the new regulations. There is a precedent in history. In 1726, the French political philosopher and landowner Montesquieu complained to the French King about the prohibition on planting new vines. Montesquieu was not successful in his demands to remove the system of planting rights. Old and recent history suggests that political forces against liberalization of planting rights are very strong. Only the French Revolution in 1789 led to a fundamental liberalization of planting rights. The "liberal period" of the $19^{\text {th }}$ century was sustained by the combination of the French Revolution's liberal ideology, the thirst for wine of Napoleon's armies and diseases that wiped out most of the French vineyards.

That said, in the past and the present, enforcement of planting rights is a major problem. In fact, despite the official restrictions, Montesquieu managed to plant his vines, allowing him to become a successful wine producer and merchant and to travel and to spend time thinking, discussing and ultimately writing up his ideas which influenced much of the Western world's constitutions. (JEL Classification: K23, L51, N43, N54, Q18)
\end{abstract}

Keywords: planting rights, wine, Common Market Organization, European Union, institutions, regulation.

\footnotetext{
* This research was funded by the KU Leuven (Methusalem Funding). The authors thank Theodore Georgopoulos, David Menival, Paola Corsinovi and seminar participants in Reims for helpful conversations and suggestions. We also thank an anonymous referee for constructive comments.

${ }^{a}$ LICOS Center for Institutions and Economic Performance, Department of Economics, University of Leuven (KU Leuven), Waaistraat 6, 3000 Leuven, Belgium. Email: giulia.meloni@kuleuven.be (Corresponding author)

${ }^{\mathrm{b}}$ LICOS Center for Institutions and Economic Performance, Department of Economics, University of Leuven (KU Leuven), Waaistraat 6, 3000 Leuven, Belgium; Centre for European Policy Studies, Brussels; and Centre for Food Security and the Environment, Stanford University. Email: jo.swinnen@ kuleuven.be

${ }^{1}$ Translation by the authors: "Posons donc pour maxime que, lorsqu'il s'agit du bien public, le bien public n'est jamais que l'on prive un particulier de son bien, ou même qu'on lui en retranche la moindre partie par une loi ou un règlement politique." (Montesquieu, 1748b, XXVI, XV, p.252).
} 


\section{Introduction}

On April 15, 2014, a consortium of all major European wine associations ${ }^{2}$ co-signed an urgent letter to all the European Union (EU) governments and the EU Commissioner for Agriculture and Rural Development complaining about the detrimental effects of new proposed regulations and restrictions on planting vineyards:

"We are extremely concerned that the [proposals] would result in an even more restrictive regime (...) it would fatally jeopardize the competitiveness of the EU wine sector in a context of international competition. It would be just irresponsible to impose (...) arbitrary or discriminatory criteria and restrictions (...)."

"We are shocked by the lack of ambition for our sector shown by our national governments. (...)

Their requests are not justified on the grounds of protecting the sector against possible oversupply (...) their requests are driven by fear, selfishness and corporatist protectionisms."

Comité Européen des Entreprises Vins (CEEV), 2014

The letter reflects the frustrations and concerns of the European wine associations. In 2014, when the wine associations wrote their letter, things looked very different than a few years earlier. In 2008, the European Union (EU) had decided to liberalize the EU's vineyard planting rights regime. The decision was in line with reforms in other agricultural markets - such as grains, oilseeds, sugar and dairy - where various regulations which distorted production allocations had

\footnotetext{
${ }^{2}$ The consortium includes the European Committee of Wine Companies (Comité Européen des Entreprises Vins CEEV) and national wine associations in France, Spain, Italy, Germany, Portugal, Greece and Belgium (i.e., Union des Maisons \& Marques de Vin-UMVIN, Fédération Française des Vins d'Apéritif-FFVA, Federación Española del Vino -FEV, Unione Italiana Vini-UIV, Federazione Italiana Industriali Produttori, Esportatori ed Importatori di Vini, Acquaviti, Liquori, Sciroppi, Aceti ed affini-FEDERVINI, Bundesverband der Deutschen Weinkellereien und des Weinfachhandels-BDWW, Associação dos Comerciantes e Industriais de Bebidas Espirituosas e Vinhos-ACIBEV, Associação das Empresas de Vinho do Porto-AEVP, Greek Wine Federation-SEO, Fédération Belge des Vins et Spiritueux-FBVS).
} 
been removed and replaced by a more market oriented policy combined with direct income support for farmers (Swinnen, 2014).

Also in the wine sector extensive regulations had led to problems of oversupply, low quality and distorted market. After a series of more timid reforms in the 1980s and 1990s, the European Commission proposed to get rid of the planting rights regime, a system which regulated and restricted vineyard planting since 1970, in line with the removal of production quotas in e.g. the dairy and sugar sectors. After two years of discussions, in 2008, the EU Ministers of Agriculture adopted the EU Commission's proposal to liberalize the planting rights as part of broader reform of the EU wine sector. ${ }^{3}$

However, almost as soon as the liberalization decision was reached in 2008, an intense lobbying campaign starts to reverse the decision. And successfully so: the liberalization of the planting right system was overturned in 2013 . Not only was the liberalization decision reversed, a series of new proposed regulations could create an even more restrictive system of planting rights regulations, depending on how the new regulations will be implemented by the member states. Facing the proposal to make vineyard planting even more restrictive, the European wine associations wrote their desperate letter to EU governments.

Recent history shows that the strength of the lobby of those in favor of vine planting regulations is more powerful than those opposing them. Moreover, a look at the longer history also does not look promising for those opposing planting rights. In fact, there is a precedent to the wine associations' letter.

\footnotetext{
${ }^{3}$ The EU Ministers of Agriculture reached a political agreement in December 2007 on the reform of the EU wine market. The decision was formally adopted by the Council of Ministers in April 2008.
} 


\section{An Advocate for the Liberty of Men and Wine}

"The accumulation of all powers legislative, executive and judiciary in the same hands, whether of one, a few or many, and whether hereditary, self appointed, or elective, may justly be pronounced the very definition of tyranny. (...) In order to form correct ideas on this important subject, it will be proper to investigate the sense, in which the preservation of liberty requires, that the three great departments of power should be separate and distinct.

The oracle who is always consulted and cited on this subject, is the celebrated Montesquieu." James Madison, 1788, Federalist, no. 47, 323-31

"Every man invested with power is apt to abuse it (...). To prevent this abuse, it is necessary from the very nature of things power should be a check to power."

Montesquieu, $1748 a$, XI, IV, p.242

In 1748, Charles-Louis de Secondat, Baron de La Brède et de Montesquieu (1689-1755), published his famous and most influential work "De l'Esprit des Lois" (The Spirit of the Laws), where he argued the need to separate the political power in three separate branches: the executive, the legislative and the judicial (Montesquieu, 1748). Montesquieu's work inspired James Madison (the "Father of the United States Constitution") and the American Founders on the separation of powers in the 1787 United States Constitution. In fact Montesquieu is the second most cited source in the period of Constitution writing - only surpassed by the Bible (Lutz, 1984). Montesquieu's ideas on the separation of powers also inspired the 1791 French Constitution and many other constitutions in the world (Lane and Ersson, 2000).

However, Montesquieu was more than a political philosopher. He was also a wealthy owner of land and vineyards in France. In this position he wrote a letter in 1726 to Mr. Le Pelletier, the just-appointed French Controlleur Général who was in charge of the finances of King Louis XV

\footnotetext{
${ }^{4}$ Translation by the authors. “(...) tout homme qui a du pouvoir est porté à en abuser (...) Pour qu'on ne puisse abuser du pouvoir, il faut que par la disposition des choses le pouvoir arrête le pouvoir." (Montesquieu, 1748a, XI, IV, p.242).
} 
(1710-1774) of France. In this essay, like today's European wine associations, he bitterly complained about the newly introduced prohibition on planting new vines:

"The prohibition on planting vines is useless because the owner knows, much better than the Minister, if the vines suffer economic losses; he calculates accurately; and, as winemaking requires financial anticipation, costs and care, as long as vines do not yield well, he is naturally led to uproot and convert his land into a different kind of revenue, less cumbersome."

Montesquieu, 1726, p.267

Montesquieu argued that the 1725 prohibition was "useless" because winegrowers were much more competent in assessing the needs of the market than public officers ("il n'y entend rien"-"they understand nothing about it"). According to Montesquieu, given the high demand for Bordeaux wines (in France and abroad such as in England, Holland and Flanders), it is in the public interest to rely on the winegrowers entrepreneurial skills to invest in the most efficient vineyards:

"[The Bordeaux wine region] must provide different kinds of wines to the foreign market, depending on the diversity of its soils. However, the taste of foreigners varies continuously (...).

We must therefore follow this inconsistent taste, planting or uprooting accordingly."

Montesquieu, 1726, p.267

While Montesquieu may have inspired the United States Constitution, he was not able to convince the French King (or his advisors) to get rid of planting rights. Actually, he may have made things worse when he complained that partial planting rights would only induce other regions to plant more. In fact, this was his only argument that was taken up by King Louis XV. In 1731,

\footnotetext{
${ }^{5}$ Translation by the authors. "Elle (la défense) est inutile parce que le propriétaire sait, beaucoup mieux que le Ministre, si ses vignes lui sont à charge ou non; il calcule bien exactement; et, comme la manufacture des vignes demande beaucoup d'avances, de frais et de soins, pour peu qu'elles ne rendent point, il est porté naturellement à les arracher, et à convertir sa terre en une autre nature de revenu, moins incommode." (Montesquieu, 1726, p. 267).

${ }^{6}$ Translation by the authors. "La Guyenne (...) doit fournir à l'étranger différentes sortes de vins, dépendantes de la diversité de ses terroirs. Or, le goût des étrangers varie continuellement (...). Il faut donc suivre ce goût inconstant, planter ou arracher en conformité." (Montesquieu, 1726, p.267).
} 
the King extended the prohibition to plant vines to the entire kingdom of France. The outcome was the opposite of Montesquieu's intention.

Montesquieu would not see the end of the planting rights anymore. He passed away in 1755. Four years later there was some relaxation in the planting rights system, but it is only in 1789, 34 years after the death of Montesquieu and 64 years after they were introduced, that planting rights are removed and wine production is liberalized. The thing that made it happen was ... the French Revolution. Only a dramatic political change sufficiently shifted the political equilibrium to allow a liberalization of planting rights.

What does this imply for today? As Montesquieu, the European wine associations want to remove the restrictions imposed by the planting rights regime. So the question is: what would make liberalization of the EU planting rights system possible? In the rest of this paper we document many similarities between Montesquieu's time and now in terms of the motivation for the introduction of the planting rights, their extension to other regions and problems of implementation. This comparative analysis suggests that, as planting rights were ultimately abolished and plantings liberalized only after a major political change in the $18^{\text {th }}$ century, it may require another (type of) French Revolution this time again.

\section{Planting Rights Restrictions in $18^{\text {th }}$ Century France}

"In France the anxiety of the proprietors of the old vineyards to prevent the planting of any new ones, seems to (...) indicate (...) that this superior profit can last no longer than the laws which at present restrain the free cultivation of the vine. In 1731, they obtained an order of council prohibiting both the planting of new vineyards and the renewal of those old ones (...)."

Adam Smith, 1776, p.217 
As Meloni and Swinnen $(2013,2014)$ show, many wine regulations are political responses to excessive supplies of wine, which are, in turn, often triggered by earlier periods of shortage. The regulations in France during Montesquieu's time are no exception. The domestic oversupply of wine in the early $18^{\text {th }}$ century followed earlier shortages caused by the destruction of many vineyards through extreme weather conditions and an increase in wine consumption with economic growth.

An exceptionally cold winter in Europe in late 1708 and early 1709, the Great Frost (" $L e$ Grand Hiver"), resulted in the destruction of many vineyards and in an increase in wine prices (Labrousse, 1933; Le Roy Ladurie, 1960). At the same time, demand was growing due to an increase in wine consumption in the rural areas of France. Until the beginning of the $18^{\text {th }}$ century, wine consumption was much lower in the rural areas than in the cities, where wine was consumed on a daily basis. This changed during the early $18^{\text {th }}$ century as France recovered from the constant wars of King Louis XIV of France (between 1661 and 1715). The increased well-being in the rural areas led to an increase in wine consumption. As peasants drank more wine, wine prices increased (Dion, 1959, p.597).

The increased demand and higher prices, attracted investments in vineyard plantings. The extension of new vineyards was most important in the regions of Touraine, Anjou and Bordeaux. Martin (1907, p.19) notes that King Louis XV was informed that: "in the best areas of the Bordeaux province, the residents abandoned (...) the cultivation of arable land, to engage in (...) the planting of vineyards in the hope of finding a substantial profit in wines that the foreigners are in the habit of buying."7

\footnotetext{
${ }^{7}$ Translation by the authors. "Le Roy étant informé que dans les meilleurs cantons de la généralité de Bordeaux, les habitants ont depuis plusieurs années abandonnés la culture des terres labourables, pour se livrer par préférence à la plantation des vignes, dans l'espérance de trouver un profit considérable dans les vins que les étrangers sont dans
} 
It was also pointed out to King Louis XV that these vineyard plantings occurred "without reflecting on the disadvantages that result from too great abundance". ${ }^{8}$ French wine production increased strongly around 1720 as farmers and landowners started to plant vines instead of grain (since winegrowing was more profitable), and because new (younger) vines are more productive than older ones. ${ }^{9}$ Not surprisingly, wine prices declined significantly with production growth.

With their returns from the market declining, the owners of existing (older) vineyards in the renowned and established wine regions turned to the government to support them. ${ }^{10}$ Many belonged to rich and influential families. ${ }^{11}$ They pressured both the Council of State (Conseil $d^{\prime}$ Etat $)^{12}$ and the local administration (intendant) ${ }^{13}$ to intervene (de Tocqueville, 1856; Smith, 1776; Unwin, 1991). In France, two institutions were in charge of the local administration: the "parlements" (regional courts) which were the highest juridical organizations and the "généralités" (provinces) which governed the police and the economy of the area. Membership of both institutions was limited to clergy and nobles (Brink, 1986).

l'habitude d'enlever (...)." (Extract from the edict of the Council of State on the prohibition to plant vines in Bordeaux without permission from the King - February 27, 1725. In: Martin, 1907, p.19).

${ }^{8}$ Translation by the authors. “(...) sans faire réflexion aux inconvénients qui résultent de la trop grande abondance (...)." (Extract from the edict of the Council of State on the prohibition to plant vines in Bordeaux without permission from the King - February 27, 1725. In: Martin, 1907, p.19).

${ }^{9}$ In the first three years of life, vines do not yield (almost) any wine. Then it takes another three years (on average) before vines reach their fixed limit of expansion and their yield stabilize before decreasing again. The consensus is that older vines make better wine; and that younger vines are more productive but of lower quality (Robinson, 2006, p.740).

10 This is consistent with political economy mechanisms that influence agricultural protection and price policy (see Anderson et al., 2013; Swinnen, 1994).

${ }^{11}$ In 1755, three-quarters of their income was deriving from wine sales (Brut-Moncassin, 2006, p.196)

${ }^{12}$ From the $15^{\text {th }}$ to the $18^{\text {th }}$ century, the Council of State was part of the French's state administration, in charge of advising the King on judicial matters (Brink, 1986).

${ }^{13}$ The key person of the local administration was the intendant who represented the King in each of the provinces (or généralités) and reported directly to the Controlleur Général ("Intendant", 2014). 
The lobby efforts were successful: between 1722 and 1731, various regulations were introduced to reduce the supply of wine (see Table 1). For example, in Guyenne -an historic region in southwestern France which corresponds to the present-day Gironde, Lot-et-Garonne, Dordogne, Lot, and Aveyron departments and which includes the Bordeaux wine region- the existing owners of vineyards were nobles or magistrates. ${ }^{14}$ They typically owned vineyards on the slopes in the traditional Médoc region, situated north of Bordeaux. ${ }^{15}$ In contrast, the "fury of plantings" concerned mostly vineyards in the vast plains south of Bordeaux (Enjalbert, 1953; Johnson, 1989, p.256-58). The existing vineyard owners lobbied Mr. Boucher, the intendant of Guyenne, who wrote to Mr. Dodun, Controlleur Général in charge of the King's finances. In his letter, the intendant of Guyenne proposed to uproot at least one third of the vines planted since 1709 (Montesquieu, 1726). ${ }^{16}$ Successively, Mr. Dodun wrote a report to the King of France, Louis XV on the overplanting of vines in the Bordeaux area.

In 1725, the Council of State forbade planting of new vines in the Guyenne province (the Bordeaux wine region) without an "express permission" of the King of France. ${ }^{17}$ The mentioned

\footnotetext{
${ }^{14}$ A century before, when Olivier de Serres (1600) writes his famous agricultural treatise, he analyzes the vineyards of Bordeaux and the involvement of the upper class in winemaking. He concludes that the quality of wine is related to the quality of the winegrower: "The esteemed man produces good wine" [Translation by the authors: "Que celui est estimé homme de bien, qui a de bon vin"] (Serres, 1600, p.200).

${ }^{15}$ The most influential and wealthy magistrate was Nicolas-Alexandre, Marquis de Ségur (1697-1755) known as the Prince des Vignes (Prince of Vines) who owned various properties near Bordeaux, including the renowned Castles of Lafite, Latour and Mouton. The Prince des Vignes managed to lower his taxes by lobbying Mr. de Tourny (the intendant of Guyenne) after a bad vintage of 1744 (Johnson, 1989, p.257).

16 “(...) it was hoped to uproot, at least, one third of those [the vines] who had been planted since 1709" [Translation by the authors: “(...) qu'il auroit été à souhaiter qu'on arrachât, au moins, un tiers de celles [les vignes] qui avoient été plantées depuis 1709"] (Montesquieu, 1726, p.264).

17 "The King (...) orders (...) that it shall be no new planting of vines in the province of Bordeaux without express permission of His Majesty, under penalty of three thousand livres of fine and more (...)." [Translation by the authors: “(...) oui le rapport du sieur Dodun, conseiller ordinaire au conseil royal, controlleur général des finances, le Roy (...) ordonne (...) il ne sera fait aucune nouvelle plantation de vignes dans l'étendue de la généralité de Bordeaux sans une permission expresse de Sa Majesté, à peine de trois mille livres d'amende et de plus grande (...)."] (Extract from the edict of the Council of State on the prohibition to plant vines in Bordeaux without permission from the King - February 27, 1725. In: Martin, 1907, p.19).
} 
reason for the edict was "to provide for the best interests of the inhabitants of Bordeaux", ${ }^{18}$ which in reality were the best interests of the existing vineyard owners. Yet, the Council of State did not follow the proposed "uprooting" plan and only prohibited new plantings.

Other provinces, including Champagne (the Châlons province), also issued royal edicts forbidding the planting of new vines. ${ }^{19}$ And some regions did introduce uprootings: the regional court of Metz (located in the northeast of France) forbade the planting of new vines and ordered the uprooting of all vines planted before 1700 (Denis, 1995; Dion, 1959, p.598).

\section{Regulations Breed More Regulations}

"Moreover, this prohibition is pernicious because either it is general for the whole kingdom, or not. (...) This prohibition is pernicious by being too narrow-minded: as the other provinces can indiscriminately and freely plant their vines" 20

Montesquieu, 1726, p.267

In his petition against the authorities, Montesquieu not only declared that the 1725 prohibition to plant vine was "useless" but also that it was "pernicious" and "narrow-minded", unless it would be applied to the entire kingdom. If limited to a certain region (i.e., the Bordeaux wine region), the neighboring areas could still freely plant their vines and produce cheaper wines

\footnotetext{
${ }^{18}$ Translation by the authors. “(...) à quoy Sa Majesté désirant pourvoir pour le propre intérêt des habitans de ladite généralité de Bordeaux (...)." (Extract from the edict of the Council of State on the prohibition to plant vines in Bordeaux without permission from the King - February 27, 1725. In: Martin, 1907, p.19).

19 “(...) many Council's edicts were issued to this purpose, by which all new planting of vines have been forbidden without express permission of His Majesty, in the généralités of Tours, Bordeaux, Auvergne, Châlons, Montauban and in the province of Alsace (...)" [Translation by the authors. "(...) il auroit esté rendu différents arrests du Conseil, par lesquels toutes nouvelles plantations de vignes ont esté défendues sans une permission expresse de Sa Majesté, dans les généralités de Tours, Bordeaux, Auvergne, Châlons, Montauban et dans la province d'Alsace (...)"] (Extracts from the edict of the Council of State extending to the whole kingdom the prohibition to plant vines without permission - June 5, 1731. In: Martin, 1907, pp.27-29).

${ }^{20}$ Translation by the authors. "D'ailleurs, cette défense est pernicieuse: car, ou elle est générale pour tout le royaume, ou non. (...) cette défense est pernicieuse en ce qu'elle est trop bornée: car, les autres provinces étant dans la liberté de planter, elles le font indifféremment." (Montesquieu, 1726, p.267).
} 
at prices that could undermine the reputation (and prices) of Bordeaux wines. Hence local planting rights have negative effects: "if the same precautions are not taken in neighboring provinces, the remedy would be a very poor one". ${ }^{21}$

Montesquieu made these arguments because he was against state intervention. ${ }^{22}$ His assessment on the effects of the prohibition on planting vines turned out to be visionary - but not his anticipation of the policy response.

As Montesquieu had predicted, these restrictions were "pernicious" in that they just resulted in substitution of wine from other regions. The neighboring areas of Bordeaux (as Quercy, Languedoc, Saintonge, Aunis and Poitou) planted more vineyards and flooded the Guyenne region (Martin, 1907).

However, instead of following Montesquieu's proposal to liberalize, King Louis XV decided to do the opposite. Once again, the existing vineyard owners lobbied the French administration. And again they were influential. In 1731, following three years of good grape harvests, his "remède" ("remedy") was to extend the prohibition to plant new vines to the entire French kingdom. The 1731 edict stated that:

"there shall be no new planting of vines in the provinces of the kingdom, and that those who have been two years without being cultivated cannot be replanted without express permission of His Majesty". ${ }^{23}$

\footnotetext{
${ }^{21}$ Translation by the authors. “(...) si l'on ne prenoit pas les mesmes précautions dans les généralitez et provinces voisines, le remède ne procureroit qu'un bien médiocre (...)." (Extracts from the edict of the Council of State extending to the whole kingdom the prohibition to plant vines without permission - June 5, 1731. In: Martin, 1907, pp.27-29).

22 In the French edition of The General Theory of Employment, Interest and Money, John Maynard Keynes provocatively described Montesquieu as "the real French equivalent of Adam Smith. The greatest of your economists, head and shoulders above the physiocrats in penetration, clear-headedness and good sense (which are the qualities an economist should have)." (Devletoglou, 1963).

23 "His Majesty wanted to stop the new planting of vines and overcome the disadvantages that result from it (...) there shall be no new planting of vines in the provinces of the kingdom, and that those who have been two years without being cultivated cannot be replanted without express permission of His Majesty, under penalty of three thousand livres fine (...)." [Translation by the authors: "Sa Majesté voulant faire cesser ces nouvelles plantations de vignes et remédier aux inconvénients qui en résultent (...) il ne sera fait aucune nouvelle plantation de vignes dans l'estendue des
} 
The edict clearly indicated that the measure was driven by the interests of the existing vineyard owners producing "high quality" wines: "over-abundance of vines in the kingdom that occupies a large amount of land suitable to grow grain or pastures (...) multiplied the quantity of wine to the extent that the value and reputation in many places was destroyed". ${ }^{24}$

In summary, Montesquieu's only argument that was taken up by the French King was that local planting rights are inefficient. However, instead of liberalization, the outcome was more regulations as planting rights were introduced throughout the French kingdom and restrictions were extended to the old vines (and not only on the new vines). Vines abandoned for more than two years could not be replanted without an express authorization from the King.

\section{V. $\quad$ Planting Rights Liberalization after 1789}

“(...) the Revolutionaries appeared ready to sweep through grandiose measures which would not only liberate men, but also the landed property of France."

$$
\text { Plack, 2009, p.35 }
$$

While there were significant problems with their enforcement (see further), the planting rights introduced by King Louis XV lasted for almost 70 years. They were abolished only in 1789, as part of a major political, institutional and economic transition: the French Revolution. The French Revolution started with the assault on the Bastille on 14 July 1789. It promoted liberty of

\footnotetext{
provinces et généralités du royaume, et que celles qui auront eslé deux ans sans estre cultivées, ne pourront estre restablies sans une permission expresse de Sa Majesté, à peine de trois mille livres d'amende (...)."(Extracts from the edict of the Council of State extending to the whole kingdom the prohibition to plant vines without permission - June 5, 1731. In: Martin, 1907, pp.27-29).

${ }^{24}$ Translation by the authors. "Sur les représentations qui avoient esté faites au Roy depuis longtemps, que la trop grande abondance des plants de vignes dans le royaume occupoit une grande quantité de terres propres à porter des grains ou à former des pâturages (...) et multiplioit tellement la quantité des vins qu'ils en détruisoient la valeur et la réputation dans beaucoup d'endroits." (Extracts from the edict of the Council of State extending to the whole kingdom the prohibition to plant vines without permission - June 5, 1731. In: Martin, 1907, pp.27-29).
} 
Men (Liberté) and destroyed all previous privileges. Three weeks after the assault on the Bastille, a series of decrees abolished feudalism, serfdom, seigneurial and royal privileges in place during the previous "Ancien Régime". However, it would take "over one hundred decrees and four more years until the seigneurial regime was completely dismantled"'(Plack, 2009).

The liberty principle of the French Revolution also implied vines could be planted anywhere in France. It not only removed the planting rights, it also proved to be a turning point in the political equilibrium on planting rights for the next century and a half. There was considerable lobbying by vineyard owners in the rich wine regions in the $19^{\text {th }}$ century but it was not successful in reintroducing the planting rights regime. They (unsuccessfully) pressured the French government during Consulate (1799-1804), the First Empire (1804-1814) and the Restoration (1814-1830) (Dion, 1959, p.600). ${ }^{25}$

The French governments in the $19^{\text {th }}$ century refused to introduce planting rights because they were inspired by the principles of the French revolution, favoring the rights of new winegrowers and of the masses to access cheap wines. However, they also feared popular discontent if they would reduce the supply of wine, since the French wine market in the $19^{\text {th }}$ century was mostly characterized by high demand. In the first decades of the $19^{\text {th }}$ century, the demand for wine was very high in France due to the Napoleonic wars that lasted from 1803 to $1815 .^{26}$ The wars required a continuous supply of food and drink for an army of many hundreds

\footnotetext{
${ }^{25}$ Already in 1800, a report from the Commission on Agriculture stated that in 30 years vines had multiplied by five, taking over arable land suitable for the cultivation of grain - a "radical vice". In 1808, the Empire's representative (préfet) of the Aube (Champagne region) was wishing that "vines were uprooted from the plains". Again, in 1813, the préfet of the Moselle claimed that " $a$ wise foresight had dictated the measure [planting restrictions]. It would be desirable that it was renewed" (Dion, 1959, p.602).

${ }^{26}$ In this twelve years' war period, Napoleon won 53 battles and lost 7 - with the 1815 Battle of Waterloo as one of the biggest and final defeat (Roberts, 2014).
} 
of thousands of soldiers. ${ }^{27}$ Demand for wine was high since wine was still a safer drink compared to water and it was used to "fuel" the soldiers in the battles. Many witness accounts describe drunk soldiers' actions in the battles. During the French invasion of Spain in 1808, a senior commissary officer observed that: "In the end Villafranca was literally plundered, and the drunkenness that prevailed ... led to the most shameful incidents" (Fremont-Barnes and Fisher, 2004, p.206).

Later in the $19^{\text {th }}$ century two major vine diseases reduced the supply of wine (and thus any demand for planting restrictions). About 30 years after the end of the Napoleonic wars, the outbreak of two vine diseases ravaged France's vineyards. The first wave of vine fungal disease in France (oidium or powdery mildew) showed up in 1846. In seven years, from 1847 to 1854 , wine production collapsed from 54 million to 11 million hectoliters, an $80 \%$ decline. However, the discovery of sulfur to tackle the vine disease allowed a rapid recovery. French wine production was back at 54 million hectoliters in 1858 (Insee, 1935; Paul, 1996, p.12).

Six years later, another vine disease, Phylloxera, appeared. It also had dramatic consequences and destroyed many vineyards in France. ${ }^{28}$ One-third of the French vine area was destroyed, and the remaining (infected) vineyards produced little wine. French wine production declined by about 70\% in the 1870s and 1880s (Augé-Laribé, 1950; Lachiver, 1988).

In summary, in the $19^{\text {th }}$ century planting rights did not return to France due to a combination of the dominant liberal philosophy of the French Revolution and the limited pressure to restrict supplies during several periods of excess demand caused by the high demand for wine to satisfy

\footnotetext{
${ }^{27}$ Napoleon's army was called "La Grande Armée" (The Great Army) and reached a total of about 680,000 soldiers by 1812 (Houdecek, 2012).

${ }^{28}$ Phylloxera, a parasite that lives on the vines' root systems and eventually kills the plant, originated in North America and arrived in Europe in 1863 (Augé-Laribé, 1950; Lachiver, 1988).
} 
Napoleon's armies thirst in the first half of the century and two major diseases that crippled French wine production in much of the second half.

However, as in the early $18^{\text {th }}$ century, the shortage of wine due to the devastation of the vineyards in the late $19^{\text {th }}$ century forebode a future surplus problem - and pressure to reduce supply.

\section{L'Histoire se répète. ${ }^{29}$ Planting Rights Regimes in the $20^{\text {th }}$ Century}

"This is a law of a very exceptional nature ... We believe it is, since the French Revolution, the legislation with the largest government intervention in the economy.

$$
\text { This is... a planned economy." } 30
$$

Mr. Jean-Ch. Leroy, General Counsel of the Wine Appellations of Origin, 1932

The 'liberal' wine regime (without planting rights) would last 150 years. Planting restrictions were (re-)introduced in 1931 in France (exactly 200 years after King Louis XV's 1731 planting prohibitions) and after France's integration in the European Economic Community (EEC), the precursor of the European Union (EU), planting rights would spread across Europe in the second half of the $20^{\text {th }}$ century (see Table 1 ).

The outbreak of Phylloxera and the collapse of French wine production in the late $19^{\text {th }}$ century induced major investments in vineyards in Algeria, a colony of France. The crisis induced an inflow of skills in wine-making through the migration of many broke French winegrowers to Algeria, and it caused an increase in the demand for Algerian wine. Algerian wine exports to France increased rapidly (Meloni and Swinnen, 2014).

\footnotetext{
${ }^{29}$ History Repeats Itself.

${ }^{30}$ Translation by the authors. "Il s'agit ici d'une loi d'un caractère très exceptionnel. On peut dire, croyons-nous, qu'elle constitue, depuis la Révolution française, la mesure législative la plus importante consacrant l'intervention de l'état dans le domaine de la vie économique. C'est, suivant l'expression à la mode, de l'économie dirigée au premier chef' (In: Société de législation comparée, 1932, p.96).
} 
By the beginning of the $20^{\text {th }}$ century, French vineyards had gradually been reconstructed thanks to the planting of hybrid grape varieties and the use of grafting, and production recovered. The combination of many new high productive vineyards and growing imports from Algeria caused a major surplus crisis on the French wine market. With the growing surplus, the pressure on the French government to intervene grew. This time pressure came from winegrowers located in the Midi region in southern France, organized in the Confédération Générale des Vignerons du Midi (General Confederation of Midi Winemakers-CGVM). The destructions of World War I temporarily reduced wine supplies. However as production recovered and wine prices declined in the 1920s, the pressure on the government to intervene grew. When protests turned into violence, the French government gave in and introduced a series of laws aimed at restricting the wine supply (Meloni and Swinnen, 2013).

In 1931, vine planting restrictions were (re-)introduced in France, again to protect existing vineyard owners from increased production by new and cheaper wine producers. The planting rights were part of the Statut Viticole,${ }^{31}$ the new French wine policy regime introduced to protect established French producers from increased production in Algeria and other regions of France (JORF, 1931, Article 3). In 1935, another law restricted production of certain wines to specific regions (through areas' delimitation) and to specific production criteria such as grape variety, minimum alcohol content, and maximum vineyard yields -as part of the creation of Appellations d'Origine Contrôlées (AOC) (Meloni and Swinnen, 2013, 2014).

World War II caused a temporary break in the restrictions. French production declined from 60 million hectoliters in 1938 to 29 million hectoliters in 1945 due to massive vineyard destruction. As a result, the Statut Viticole was suspended in 1942. After the war, wine demand

\footnotetext{
${ }^{31}$ Laws were issued in 1931, 1933, 1934, and 1935 (JORF, 1931, 1933, 1934, 1935).
} 
grew rapidly and supply was still low. This resulted in high prices, which encouraged vineyard replantings. Wine prices in 1946 were approximately three times those in 1939 (INAO, 1943, p.35; Insee, 1966, p.190).

As in the $18^{\text {th }}$ century and earlier in the $20^{\text {th }}$ century, wine production increased strongly in the following years, because young vines were more productive than older ones, and because of increased wine imports from Algeria. The increase in wine production reduced prices again and soon resulted in new pressure for political intervention. In 1947, the French government decided that winegrowers could only plant new vines if they had grubbed up the equivalent surface area. However, the 1947 regulation was hardly enforced and winegrowers continued to plant "illegal" vines (Warner, 1960, p.174).

In 1953, a new planting rights regime was introduced in France. The new wine policy (the Statut Viticole) was reintroduced under the name Code $d u$ Vin. The law reestablished planting restrictions and "replanting rights", subsidies to uproot vines, as well as surplus storage, ${ }^{32}$ compulsory distillation, ${ }^{33}$ and penalties for high yields (JORF, 1953; Milhau, 1953).

The restrictions in the Code $d u$ Vin were linked to production regions - based on the French "terroir" principal which through regulations links "quality" with location and which today is present in many Geographical Indications (GIs) - and grape varieties. First, the 1953 Code identified which regions were qualified for viticulture. All "other regions" were not qualified for viticulture according to the government. If there were vineyards there, then they were "regions of reconversion" and the vineyards needed to be uprooted (JORF, 1953).

\footnotetext{
${ }^{32}$ In years of overproduction, aid for private storage for their wine surplus was given to winegrowers.

${ }^{33}$ Wine distillation is the process by which wine is transformed either into raw alcohol and spirits or into industrial alcohol.
} 
Second, inside the regions officially qualified for viticulture, the restrictions were different for table wines ("low quality" wines) and AOC wines ("high quality” wines) (see Figure 1) ${ }^{34}$ AOC wines were (by AOC-definition) only produced in specific (sub-)regions (such as Bordeaux or Champagne) and new plantings were allowed under the specific AOC regulations. ${ }^{35}$ For table wines the general principle was that no new plantings were allowed.

Third, there were further distinctions within the table wines with more restrictions. New (additional) plantings were prohibited for all table wines but replanting, after vineyards had been uprooted, was allowed under strict conditions. The lowest category of grape varieties was the "prohibited" (mainly hybrids, as Noah, Othello, Isabelle, Jacquez, Clinton and Herbemont) who needed to be grubbed up and its wine distilled. The second category was the "temporarily tolerated" who could not be replanted. The third category was the "authorized" varieties. If these varieties were used, the producer had to reduce the area with $30 \%$ when replanting. The fourth category was the "recommended" grape varieties. If producers planted these grapes, they could go for the same (100\%) area as they had grubbed up. Finally, it should be noted that these "replanting rights" could not be transferred to other producers or landowners (JORF, 1953, Article 30).

The impact of the introduction of planting restrictions and subsidies to uproot vines was sizable. From 1953 to 1957, around 120,000 hectares of vines were uprooted, representing 7\% of the total vineyard area. As a consequence, French wine production declined by about $10 \%$ in the same period (Insee, 1966, p.190). Moreover, due to the policy of replanting of vines to "better vine

\footnotetext{
${ }^{34}$ In 1953, 87\% of wine in France was produced as table wine and only 13\% as AOC wine (Humbert, 2011).

${ }^{35}$ The AOC wines restricted production not only to specific regional origins (through delimitation of specific areas) but also to specific production criteria such as grape variety, minimum alcohol content, and maximum vineyard yields. AOC wines could only be produced with specific grape varieties listed in the so-called cahier des charges ("book of specifications"). For instance, for the AOC Champagne, only 7 grape varieties can be planted within the delimitation: Chardonnay, Pinot Noir, Pinot Meunier, Pinot Blanc, Pinot Gris, Arbane and Petit Meslier.
} 
varieties", in the next 10 years (1958-1968), the share of the "recommended" grape varieties increased from 58\% to 90\% of the planted grape varieties in France (Durbiano, 1975).

\section{Regulations breed more regulations - again}

Economic integration in the European Economic Community (EEC) during the 1960s and 1970s required the integration of different policy regimes in one EEC wine policy (the Common Market Organization (CMO) for wine). The most important producers, Italy and France, held different positions (see Table 2). While France's wine market was highly regulated through government intervention, including prohibitions on new vineyards and price supports, Italy had more liberal wine policies: there were no price interventions or planting restrictions.

The Treaty of Rome (1957) fixed a "transitional period" for a common policy to be negotiated and introduced. The initial EEC regulatory steps toward a Common Wine Policy was taken in 1962. It was far from a common policy and only required that each member state established a viticultural land register; the notification of annual production levels to a central authority (harvest and stock declarations); the annual compilation of future estimates of resources and requirements; and stricter rules on "quality wines". ${ }^{36}$ There was no agreement on stronger regulations such as planting rights (Council Regulation No. 24/1962). The transition period was supposed to end in 1969 and, by 1969, wine was the last major agricultural product that was still subject to national regulations. Italy and France had to reach an agreement on a common policy by the end of the year (Niederbacher, 1983; Spahni, 1988). ${ }^{37}$

\footnotetext{
${ }^{36}$ EU "quality regulations" are based on the "appellation" system and include policy instruments such as the geographical delimitation of a certain wine area, winegrowing and production rules, and rules on labeling (Meloni and Swinnen, 2013).

${ }^{37}$ Also in other agricultural commodities, such as grains, dairy, and oilseeds, there was a transition period of approximately ten years after the signing of the Treaty of Rome (in 1957) before a common market organization was fully implemented.
} 
In the absence of common EEC regulations, national wine policies continued. In 1964 there was some relaxation of planting rights restrictions in France. The main reason was the fall in Algerian wine imports. After Algeria achieved independence in 1962, France imposed import restrictions and tariffs on Algerian wine causing a dramatic decline in imports of Algerian wine and therefore in the total wine supply in France. A second factor was a decrease in Italian wine production due to a decrease of mixed crop vineyards and to the Italian miracolo economico (economic miracle) that led to massive exodus from the rural areas into the cities (Bartoli et al., 1987, p.23; Meloni and Swinnen, 2014; Niederbacher, 1983).

In 1964 two laws, on "the wine production and organization of the wine market" and on "the organization of the vineyard and improving the quality of wine production", eased rules on market intervention and especially on planting rights (JORF, 1964a and 1964b). ${ }^{38}$ First, the 1964 law allowed the transfer of wine "replanting rights" from one winegrower to another. Second, the planting of new vines was extended to table wines (and not only to AOC wines) and was allowed if justified by "favorable economic prospects and trade opportunities" or by "improving the geographical distribution of the vineyard or the structure of farms" (JORF 1964a). ${ }^{39}$

\footnotetext{
${ }^{38}$ The relaxation of the 1953 legislation allowed, for instance, producers were given more freedom to plant and irrigate their vineyards.

39 "Within the limit of a maximum amount of areas planted with new vines (...), authorizations for planting new vines may be granted for the production of table wines (...) the granting of these authorizations may however take place only if is justified by economic prospects, especially by those of foreign trade and future opportunities, or by improving the geographical distribution of the vineyard or by improving the structure of farms." [Translation by the authors. "Dans la limite d'un montant maximum de superficies plantées en vignes nouvelles (...), des autorisations nouvelles de plantations de vignes pourront être octroyées en vue de la production de vins de consommation courante et de raisins de table (...) l'octroi de ces autorisations ne peut toutefois avoir lieu que s'il est justifié par les perspectives économiques, et notamment par celles du commerce extérieur et des débouchés futurs, et s'il doit aboutir à une amélioration tant de la répartition géographique du vignoble sur le territoire que de la structure des exploitations agricoles."] (JORF 1964a, Article 3).
} 
However, restrictions were not fully removed. For example, replanting with authorized varieties was still restricted at $70 \%,{ }^{40}$ the transfer of wine "replanting rights" was subject to authorization by the Institut des Vins de Consommation Courante (IVCC) ${ }^{41}$ and new planting of table wines was allowed only if the "recommended" grape varieties were used within the regions qualified for viticulture (JORF 1964a, Articles 1 and 3). ${ }^{42}$

During the 1964-1970 period, this "more liberal" French planting regime helped to facilitate the negotiations between France and Italy. In 1970, a compromise between the positions of Italy and France formed the basis of the European Common Wine Policy (CWP). ${ }^{43}$ The 1970 CWP introduced restrictions on vine plantings for the entire EEC. The structure of the EEC planting rights regime strongly resembled the French system, but in a weaker version of implementation. First, as in the French system a distinction was made between "table wines" and "quality wines produced in a specific region" (often abbreviated to "quality wines psr" or simply "quality wines", as AOC in France or Denominazione di Origine Controllata (DOC) in Italy). Second, within the table wine regime different grape categories were introduced. Vines were classified as "recommended," "authorized," and "provisionally authorized" varieties - with

\footnotetext{
${ }^{40}$ This restriction is still in place in the latest French Rural Code: "If, when planting, authorized varieties are used, replanting rights are reduced by 30\%" [Translation by the authors. "Si, lors de la plantation, des variétés classées autorisées sont employées, les droits de replantation subissent un abattement de 30\%".] (Code Rural 2008, Article R665-16).

${ }^{41}$ The Institut des Vins de Consommation Courante (Institute of the Wines of Current Consumption-IVCC), a government branch, was established in 1953 to administer table wines and to classify grape varieties (Loubère, 1990, p.132).

42 "In addition, new planting rights for wine production are granted only if recommended varieties are used and in the regions qualified for viticulture" [Translation by the authors. "En outre, les droits de plantation nouvelle de vigne destinée à la production du vin ne sont accordés que s'il s'agit de cépages recommandés et dans les terroirs viticoles".] (JORF 1964a, Article 3).

${ }^{43}$ See Meloni and Swinnen (2013) for a discussion of the other CWP regulations.
} 
"recommended" as the highest quality level, resembling the French 1953 classification (Council Regulation No. 1388/70, Article 6). ${ }^{44}$

Restrictions were introduced on the new planting and replanting of vines to "better vine varieties" - the so-called "rules designed to improve vine-stock selection". Also in this aspect the CWP structure resembled the French system but under Italian pressure the implementation was weakened. In the EEC, new plantings in "quality wines" (e.g., AOC and DOC) regions was allowed for both "recommended" and "authorized" grape varieties. Similarly, "authorized" varieties were also allowed for new plantings of table wines under EEC rules. However, France applied more restrictive national regulations (as allowed under EEC rules) and still imposed only "recommended" grape varieties for AOC regions and the "70\% replanting rule" for table wines (Council Regulation Nos. 816/70 and 817/70; JORF, 1972). ${ }^{45}$

However, the compromise on the planting rights regime did not last very long. There was continued pressure from France for a more interventionist approach and this pressure grew stronger with increasing imports of Italian wine. A full-blown "wine war" exploded in 1974, when increasing grape harvests in 1973 and 1974 and a devaluation of the Italian lira lowered prices of exported Italian wines. In 1975, French growers physically blocked Italian wine imports at the French ports. In 1976, under growing pressure from French producers, who feared that cheaper Italian wine would swamp the French market and cause a collapse in prices, the European Council

\footnotetext{
${ }^{44}$ The EEC system of notification was similar to the French "authorization" system. Winegrowers wishing to plant/replant vines had to notify the relevant authority. Member states had to document these notifications by "issuing a licence prior to the planting or replanting". The implementation of this was left to member states (Council Regulation No. 816/70, Article 17).

${ }^{45}$ As in France, there was a ban on the "provisionally authorized" varieties. The wine made from vines not included in the classification was eliminated from the market and distilled (Council Regulation No. 816/70, Articles 15 and 16).
} 
of Ministers introduced stricter measures to control the supply of wine through more stringent planting rights restrictions and other policies such as subsidized grubbing-up (i.e., uprooting). ${ }^{46}$

The 1976 regulation on vineyard plantings, contrary to the 1970 regulation, not only restricted the replanting of vines to "better vine varieties"- but imposed a total ban on all new plantings for table wines. ${ }^{47}$ Furthermore, member states had to uproot hybrid grape varieties by 1979 and to uproot "provisionally authorized” grape varieties by 1983 (Council Regulation No. 1160/76).

The tighter regulations of planting rights were initially perceived as a temporary measure and only affecting "low quality" wines. In fact, the 1976 regulation stated that "All new planting of vine varieties (...) shall be prohibited during the period from 1 December 1976 to 30 November 1978" (Council Regulation No. 1162/76, Article 2). However, since then the system has been continuously re-confirmed and it has been continued over the years (becoming a permanent one) and even expanded to include also "high quality" wines in 1984 (Council Regulation No. 1208/84).

Hence, by the mid-1970s, instead of being liberalized, the French wine policy with its extensive regulations and heavy government intervention in markets had become the official European wine policy. As during the reign of King Louis XV, instead of loosening regulation to solve problems of market distortions, the opposite happened: politicians introduced more restrictions and extended them to other regions to control supply there as well.

\footnotetext{
46 The EU provides grubbing-up premiums to winegrowers who permanently (and voluntarily) abandon existing vineyards. Under this scheme, wine-growers can decide, on a voluntary basis, to eliminate "all vine stocks on a parcel planted with vines" and replace them with other agricultural crops and apply for funding for abandoning their vineyards (the grubbing-up premium) (Meloni and Swinnen, 2013).

47 "Member states shall no longer grant authorizations for new plantings" with three exemptions to the general ban. The three exceptions were: (a) new planting intended for the production of quality wines psr in Member States whose production of quality wines psr was less than $50 \%$ of the total wine production; (b) new planting carried out under development plans; (c) new planting carried out in Member States which produce less than 5000 hi of wine annually using grapes harvested on their territory (Council Regulation No. 1162/76, Article 2).
} 


\section{Enforcement Problems}

"As France was divided into an infinity of small lordships, which recognized feudal dependency rather than political dependency, it would have been very difficult for a single law to have authority: indeed, one could not have seen to its enforcement."48

Montesquieu, 1748b, XXVIII, IX, p.297

An important problem with the implementation of planting rights restrictions (and with quantitative restrictions on output and input use in general $^{49}$ ) is the enforcement of the regulations. Major problems of enforcement of the EU planting rights system received a lot of publicity in 2012 when the European Commission fined Greece, Italy and Spain for a total of 250 million euros because of 120,000 hectares illegally planted vineyards, around $8 \%$ of total vineyard area. For instance, in Italy more than 24,000 hectares (equal to about 34,000 soccer fields) of illegal vine planting were found (73\% of them were found in the Puglia region, in southern Italy) (Corsentino, 2012).

Given that technologies have improved so much over the past two centuries it is not surprising that enforcement was even more problematic in the $18^{\text {th }}$ century. Martin (1907) argues that the 1731 edict did not restrict plantings effectively, and that they were more planted vines in the 1750 s than in $1731 .^{50}$

The edict was weakly enforced for two main reasons. The first reason was the "freedom of interpretation" of the intendants in charge of controlling and enforcing the restrictions on the vine

\footnotetext{
${ }^{48}$ Translation by the authors." D'ailleurs, la France se trouvant divisée en une infinité de petites Seigneuries, qui reconnaissoient plutôt une dépendance féodale qu'une dépendance politique, il étoit bien difficile qu'une seule Loi pût être autorisée." (Montesquieu, 1748b, XXVIII, IX, p.297).

${ }^{49}$ Problems of enforcement is an important reason why production quota have been implemented in the EU dairy and sugar sector but not in e.g. grains and oilseeds (Swinnen, 2014).

${ }^{50}$ In 1756, Mr. de Tourny (the intendant of Guyenne) wrote a letter to Mr Moras (the Controller General) where he stated that they were more planted vines than in 1731 and where he confirmed the need of maintaining the planting rights system (Martin, 1907, p.136).
} 
planting. Initially, the municipalities inspected whether new vines were planted. This changed during the 1740s. Independent persons were appointed. They were in charge of preparing reports on the existence of new planting of vines. Based on these reports, the intendant issued the sentences. If new vines were found, the vineyard owners were sued in court and legally punished with fines of three thousand livres. ${ }^{51}$ However, in 1737, the 1731 edict was adjusted so that vines could be planted if the winegrower was able to prove that the land was not suitable to grow grain. ${ }^{52}$ In practice this implied that the edict could (and did) have different effects depending on whether the intendant in charge of enforcing the edict was willing (or not) to accept the arguments of the winegrower. Dion (1959, p.599) argues that this led to a gradual erosion of the 1731 edict.

Another reason was the different interests of wine producers in regions such as Bordeaux and those located in the Midi region in southern France. After the end of the wars with France that lasted from 1689 to 1713 , Britain decided to impose high tariffs on French wines in $1714 .^{53}$ Volume tariffs on wine (and not ad valorem) hurt especially the export of cheap wines to Britain. It allowed the upper British class to continue to consume "high quality" wines while the lower class moved to beer (Nye, 2007). Therefore, the British tariffs encouraged landowners in Bordeaux to produce "higher quality" (price) wines to continue to export them to England. The landowners

\footnotetext{
${ }^{51}$ For instance, in 1748, Mr. de Tourny (the intendant of Guyenne) enforced 13 fines of three thousand livres based on the reports of Mr. Duval (Martin, 1907, p.88).

${ }^{52}$ There are interesting parallels with the policy debates on the use of land for food and alcohol production at different times in history. In the current EU debate on biofuels, some object to the use of agricultural land for biofuels (including ethanol) or renewable energy (RE) production in order to use the land for food production - and keep food prices low. This is an interesting U-turn in the policy debate since before the food price spike of the late 2000s, biofuel and nonfood use of agricultural products were seen as a way of raising agricultural prices and thus EU farm incomes (Swinnen, 2011). This debate on the competition between food and alcohol for the use of land also has more ancient roots. In ancient Rome, Emperor Domitian promulgated an edict in the year $92 \mathrm{AD}$ that imposed the destruction of half of the existing vineyards in the Roman provinces and forbade the planting of any new vines in the Italic peninsula in order to stimulate grain production needed to supply Rome and its legions (Meloni and Swinnen, 2015).

${ }^{53}$ For an extensive analysis on the political economy of Anglo-French trade, 1689-1900, see the work of John Nye (2007).
} 
were supervising the entire wine making process and planting lower yielding grapes on the slopes. On the contrary, in the Midi, the landowners were not exporting their wines nor aiming at increasing their quality. They just wanted more wine to increase their profits and therefore wanted to plant higher yielding and more grapes (Dion, 1959, p.598; Enjalbert, 1953; Lacouture, 2003, p.134).

Problems of implementation continue today. In their study of the current EU planting rights, Montaigne et al. (2012) point out that "the lack of efficient controls and the non-compliance by winemakers" as a major problem. Without appropriate enforcement, the aim of a planting rights regime (i.e., restricting supply) is undermined.

The enforcement of the regulation is, in the first place, the responsibility of the member states. They have to manage "appropriate control systems", i.e. a vineyard register, a planting rights register and the associated controls. If the member states discover "unlawful" or "illegal" plantings (i.e., areas planted with vines without a corresponding planting right), they must order the uprooting of these plantings and punish the winegrowers with fines of 12,000 euro per hectare per year until the grubbing-up is done (European Commission, 2012).

An additional control is made by the European Commission who can fine growers for illegal vine planting. The last control was made after the 2008 CMO reform, where winegrowers could "regularize" the illegal plantings planted before 1998 against the payment of a fee. However, as the 2012 fines illustrates, many illegal plantings remain. 


\section{Attempts to Reform the EU Planting Rights}

"It took three years of hard work with ups and downs, but in the end the sector scored the winning goal (...): the Europeans gods heard our prayers or so to say."

\section{European Federation of Origin Wines's blog 54}

There have been several proposals to reform the EU wine policy and the planting rights system. The most serious attempt -which initially appeared successful- occurred in the second half of the 2000s.

Liberalization of the EU current system of planting rights was widely discussed since 2006, when the European Commission proposed a set of bold reforms, which included the elimination of planting rights. The European Commission proposed that planting rights restrictions should be removed by 2013, allowing producers to freely decide where to plant. The reform proposals were in line with the abolition of production quota in the dairy and sugar sectors and reforms in other agricultural sectors which had been decided earlier.

In 2008, the EU leaders approved this major reform of the Common Wine Policy. ${ }^{55}$ A key component was the abolition of the planting rights system. However, the Council of Ministers decided to allow a long transition period: the member states wishing to continue the restrictions could do so until 2018.

\footnotetext{
${ }^{54}$ EFOW, the European Federation of Origin Wines, was established in 2009 to lobby against the liberalization of planting rights. EFOW includes the French Organization of Appellation of Origin Wine Producers (CNAOC), the Italian Association of Geographical Indication Wine Consorzi (FEDERDOC), the Spanish Conferencia Española de Consejos Reguladores Vitivinícolas (CECRV), the Portuguese Port and Douro Wines Institute (IVDP) and the Hungarian Hegyközségek Nemzeti Tanácsa (HNT). In 2010, EFOW created a blog to debate the end of planting rights scheduled for 2016.

${ }^{55}$ See Meloni and Swinnen (2013) for more details on the 2008 CMO reform.
} 
Although the reform was approved by a qualified majority ${ }^{56}$-significantly more than a simple majority of votes- in the Council of Ministers, interest groups opposed to the liberalization immediately started to re-organize and launched a new lobby campaign. They succeeded in changing many member states' position. The first countries to express their wish to overturn the decision were Germany and France in 2010. Since then, all EU member states that produce wine joined in asking for a continuation of planting rights (Deconinck and Swinnen, 2015; EFOW, 2012). This led to a creation of a High Level Group (HLG) on Wine Planting Rights ${ }^{57}$ and a joint decision by the European Parliament and the Council of Ministers in 2013 to extend the planting rights system until 2030 with a new program of authorizations for new plantings starting in 2016 - effectively overturning the 2008 decision to liberalize (Gaeta and Corsinovi, 2014). ${ }^{58}$

There is discussion on whether the new planting rights system is even more restrictive than the existing one. In principle, the new "authorization" system could be either more or less restrictive, depending on how the new regulations will be implemented by the member states. Interestingly, these implementation decisions may change yearly, making an ex-ante assessment difficult.

The new EU-wide "authorization" system will be (once more) based on the French authorization system. ${ }^{59}$ One major difference between the "planting rights" system (as it was

\footnotetext{
${ }^{56}$ Most decisions in the Council of the European Union (often referred to as the Council of Ministers) are taken by qualified majority - a system of weighted votes. The number of votes given to each member state is weighted according to its size and population. For instance, France, Germany, Italy and the United Kingdom have 29 votes each and Malta has 3. The total number of votes is currently 352 and to adopt a proposal 260 votes are required (e.g. the qualified majority) instead of a simple majority of votes (Council of the European Union, 2014).

${ }^{57}$ The HLG was created to make recommendations on the future EU regulation on vine plantings by the end of 2012.

${ }^{58}$ There is an interesting question to what extent the institutional reform which introduced "co-decision" on the wine policy (as on other Common Agricultural Policy issues) was a crucial factor in the reversal of the decision. Co-decision implies that the European Parliament has to approve the decision together with the Council. For discussions on the impact of co-decision, see Crombez et al. (2012) and Knops and Swinnen (2014).

${ }^{59}$ In France, in addition to the "planting rights", winegrowers also need an "authorization" to plant vines.
} 
implemented in many other EU countries) and the "authorization" system (as applied in France) is the tradability of the rights. In many EU countries, the "planting rights" can now be traded whereas the "authorizations" will be individual and non-transferable. Another major difference is that the ability to plant new vines is now extended to wines without a GI (thus not only to PDO/PGI wines). ${ }^{60}$ In addition, these authorizations for new plantings have an annual maximum percentage of growth (corresponding to $1 \%$ of the member states total area planted with vines). For instance, in France it corresponds to 8,057 hectares per year (see Table 3; Regulation No. 1308/2013). ${ }^{61}$

In 2014, fourteen EU wine producing countries requested for new implementation criteria, such as the possibility to increase the restrictions for replanting on grape varieties or on the "immediate geographical neighbourhood areas to existing vineyards" (CEEV, 2014). ${ }^{62}$

These developments triggered the open letter of the European wine associations fearing that the recently agreed vine planting authorizations system could result in "an even more restrictive regime" than the former planting rights scheme (CEEV, 2014). In their open letter, the CEEV claimed that these "technical details" and "implementations rules" for applying the new system from 2016 were a "shopping-list of disparate requests" that would lead to a regime "more restrictive than the previous one, in clear contradiction with the spirit and the letter of the reform". The European wine associations were "shocked" by this back-door mobilization and believed that

\footnotetext{
${ }^{60}$ The 1970 EEC classification ("quality wines" and "table wines") was replaced in 2008 with another classification: "wines with a Geographical Indication (GI)" and "wines without a GI." Within the first category, there are two subcategories: Protected Designation of Origin (PDO) wines and Protected Geographical Indication (PGI) wines, with PDO as the highest quality level (Meloni and Swinnen, 2013).

${ }^{61}$ The decision was a compromise between the European Parliament that wanted a longer scheme (until 2030) but a lower limit for large vineyards $(0.5 \%)$ and the Council of Ministers that wished for a higher maximum yearly increase (2\%) but a different end-date (2024 and not 2030) (AGRA FACTS, 2013). However, French winegrowers already asked in June 2015 more than 8,000 hectares of new authorizations, above the 1\% threshold. As a result, European wine associations are already thinking of increasing the percentage during a possible "mid-term review" of the Common Agricultural Policy (CAP) in 2017.

62 This occurred during the 2013 Common Agricultural Policy (CAP) negotiations (through the so-called delegated and implementing acts).
} 
these requests were only justified on the grounds of protecting " $a$ bunch of privileges driven by domestic narrow interests".

The final rules (delegated and implementing regulations) are now published (Regulation No. 2015/560; Regulation No. 2015/561). However, the political debate will continue at the national level, as the implementation rules can be changed. It is therefore still not fully clear how the new vine planting system will be implemented by the member states in the coming years.

Every year three type of decisions can be made. First, member states will be able to establish a lower threshold (lower than 1\%) at national or regional level for new plantings - the so-called "safeguard mechanism". ${ }^{63}$ Even if at national level the threshold is maintained at $1 \%$, regions (or even smaller areas eligible for specific PDO/PGI) could still decide to lower the threshold. Second, member states can decide to impose restrictions on the allocation of the authorizations. If requests by winegrowers for new plantings are below the $1 \%$ threshold, all requests will be accepted. However, if the requests exceed the $1 \%$ threshold, authorizations shall be granted either according to a "pro-rata distribution of hectares to all applicants" or according to "objective and non-discriminatory priority criteria" which can vary substantially. ${ }^{64}$ Third, restrictions can be imposed on the replanting of PDO/PGI wines through a recommendation from a professional organization (i.e., wine producers association) (Regulation No. 2015/560; Regulation No. 2015/561). ${ }^{65}$

\footnotetext{
${ }^{63}$ These limitations have to be justified either by (a) "the need to avoid a well-demonstrated risk of oversupply of wine products in relation to market prospects for those products, not exceeding what is necessary to satisfy this need" or (b) "the need to avoid a well-demonstrated risk of significant devaluation of a particular protected designation of origin or a protected geographical indication." (Article 63, Regulation No. 1308/2013).

${ }^{64}$ There are eight priority criteria established by the European Commission, e.g., producers who are setting up vine plantings for the first time; areas where vineyards contribute to the preservation of the environment; areas facing natural or other specific constraints; projects with the potential to improve the quality of products with geographical indications (Article 64, Regulation No. 1308/2013; Annex II, Regulation No. 2015/560).

${ }^{65}$ In theory the replanting are now automatically granted ("the granting of authorizations to producers grubbing up an existing vine area should be automatic upon submission of an application") (Regulation No. 1308/2013). However,
} 
In summary, in the current authorization system, restrictions to control the supply of wine can be imposed on the total amount of land available for new plantings (1\% or less), on the way these new plantings are allocated to winegrowers, and on the replantings of PDO/PGI wines. Moreover, these are yearly decisions ${ }^{66}$ determined by member states and professional organizations according to national and PDO/PGI priorities, thereby strengthening regional power. $^{67}$

To illustrate the different outcomes that are possible, consider two (extreme) scenarios. One scenario which could give greater flexibility to the wine sector is that of a $1 \%$ yearly expansion in vineyard areas, a pro-rata distribution of new plantings and no replanting restrictions on PDO/PGI wines. This would allow innovative wine producers to plant wines without a GI (outside the production rules established within the GI areas) and to plant, for instance, different varieties than those imposed by the PDO/PGI areas - also to adapt to climate change or different consumer tastes and preferences. ${ }^{68}$ However, another scenario which could also be possible is that of a

\footnotetext{
Member States may, under certain circumstances and in areas eligible for the production of PDO/PGI wines, restrict the replanting on the basis of a recommendation from a professional organization "provided that the decision is justified by the need to avoid a well-demonstrated risk of significant devaluation of a specific protected designation of origin or protected geographical indication" (Article 4, Regulation No. 2015/560).

${ }^{66}$ Every year, member states have to submit nine documents to the European Commission: (a) the communication on wine-growing areas; (b) the notifications on the limitations on the $1 \%$ threshold; (c) whether Member States decide to apply the priority criteria; (d) a notification on the restrictions decided by Member States in relation to replantings; (e) an updated national list of professional organizations or interested groups of producers; (f) the communication on the total size of the areas ascertained as planted with vines without an authorization as well as the non-authorized areas grubbed up; (g) a notification on the applications for authorizations for new plantings requested, on the authorizations effectively granted and refused by the applicants during the previous year; (h) a notification on the authorizations for replantings granted during the previous wine year; (i) a notification on the authorizations granted during the previous wine year on the basis of the conversion of valid planting rights (Article 11, Regulation No. 2015/561).

${ }^{67}$ The power of the professional organizations will be crucial in lowering the $1 \%$ threshold, in applying replantings restrictions or in allocating new plantings. For instance, in 2015, only 9\% of the new authorizations will produce wines without a GI (JORF, 2015).

${ }^{68}$ As mentioned earlier, in the previous "planting rights" system, replanting rights could only be used to produce wines with a GI. This rule severely limits experimentation as it is simply not possible to buy planting rights to start producing a wine outside an existing GI region. Moreover, new producers cannot produce wines which do not conform to the existing rules laying down how wine in the GI region should be produced. As a result, new winegrowers are forced to produce existing products.
} 
threshold lower than 1\%, a "priority" allocation of new plantings (for instance, restricting authorizations to vineyards located in slopes with terraces or to winegrowers that grow certain grape varieties) and replanting restrictions on PDO/PGI wines. This would imply that the new authorization system could be more restrictive than the previous one.

\section{Why liberalization may require another French Revolution}

The previous section explained how -similar to the EEC decision-making on wine during France's integration into the EEC in the 1970 s- even a qualified majority vote in favor of planting rights liberalization in the 2000s ultimately was only a temporary (and non-effective) step towards liberalization. Opposition to the liberalization overcame even this 'obstacle', successfully using the political strategy of emphasizing member states" "fear of oversupply" and of "significant devaluation of a PDO/PGI'.

In historical perspective these arguments are very similar to the 1731 edict of King Louis $\mathrm{XV}$ which stated that the planting rights measure was driven by an "over-abundance of vines in the kingdom (...) to the extent that the value and reputation in many places was destroyed". Another remarkable point of similarity is the discussion regarding production on hill slopes versus production in the plains. ${ }^{69}$ The final document of the High Level Group on Wine Planting Rights (2012, p.16) states that: "there is a risk that production would move from that kind of fragile areas [areas in slopes] to lower cost production areas in the plains where higher yields could be obtained." The similarity to the 1725 edict is remarkable as it protected the vineyards on the slopes

\footnotetext{
${ }^{69}$ Interestingly, the Romans were also aware of the "hills versus plains" production. Vergil, in his Georgics (first century B.C.), states that: "apertos/Bacchus amat colles" ("Bacchus loves open hills") (Book II, lines 112-113).
} 
by forbidding vine plantings in the "uncultivated part, commonly called the swamps or the 'moors of Bordeaux", the vast flat plains south of Bordeaux. ${ }^{70}$

In summary, one can only conclude that the political forces against liberalization of planting rights are very strong. Old and recent history suggests that planting rights liberalization is possible but only under exceptional political and economic conditions. Major economic events (the destruction caused by World War II which caused a 10 year break in the planting rights restrictions in 1942-1952 and the dramatic fall in Algerian wine imports which contributed to a relaxation in 1964-1970), major institutional changes (France's integration in the EEC which resulted in a temporary compromise in 1970-1975) or political decisions (an EU qualified majority vote in favor of liberalization which was turnover before it could be implemented) only caused short periods of liberalization and proved not strong enough to effectively overcome the strong opposition in the long run.

Only the French Revolution led to a fundamental liberalization of planting rights at the end of the $18^{\text {th }}$ century (after being in place for almost 70 years). The "liberal period" of the $19^{\text {th }}$ century was sustained by the combination of the French Revolution's liberal ideology, the thirst for wine of Napoleon's armies and diseases that wiped out most of the French vineyards. Even for those in favor of the liberalization, these condition must be a frightening prospect.

\footnotetext{
${ }^{70}$ Translation by the authors. "(...) partie non cultivée, vulgairement appelée landes ou Bruyères de Bordeaux." (Montesquieu, 1726, p. 267).
} 


\section{Epilogue}

"But I believe that my old castle and my vats will soon call me to the country; for since the peace ${ }^{71}$ my wine becomes more and more in vogue amongst the English, much more so than even my book."

Letter of Montesquieu to the Grand Prior Solar, 1749

"The Code is more like 'guidelines' rather than actual rules."

Captain Hector Barbossa ${ }^{72}$

Montesquieu, differently from other writers and philosophers that depended on the generosity of wealthy patrons, maintained his financial independence thanks to the profits he made out of wine trade (Brut-Moncassin, 2006, p.191; Lacouture, 2003, p.10). ${ }^{73}$ At the time of the 1725 edict, Montesquieu already owned 216 hectares of vines in the Bordeaux wine region: 11 hectares of vines in La Brède, ${ }^{74} 75$ hectares of vines in Rochemorin (Martillac), 60 hectares of vines in Raymond, 70 hectares of vines in Montesquieu (where he produced Armagnac), and a few vines in Clairac (Brut-Moncassin, 2006, p.208). ${ }^{75}$

Since his wine constituted the wealth of his estate, Montesquieu wanted to plant more vineyards. Despite the 1725 regulation, in 1726 he acquired lands (about 10 hectares) in Pessac in

\footnotetext{
${ }^{71}$ The war of the Austrian Succession (1740-48) followed a period of peace in Europe.

${ }^{72}$ Quote from the "Pirates of the Caribbean: The Curse of the Black Pearl", 2003 British-American film directed by Gore Verbinski.

73 "I have not wanted to make my fortune by means of the Court; my design has been to make it by improving my lands" [Translation by the authors. "Je n'ai pas aimé à faire ma fortune par le moyen de la cour; j'ai songé à la faire en faisant valoir mes terres"] (Montesquieu, 1720/1835, p.621).

${ }^{74}$ Franck, (1845, p.143) states that: "In the municipalities of La Brède (...) vineyards give only ordinary wine" [Translation by the authors. "Dans les communes de La Brède (...) les vignobles ne donnent que des vins ordinaires"].

${ }^{75}$ Montesquieu expanded invested in land throughout his entire life. It was said that: "There is no house, field, vineyard, tuft of grass in that area that does not belong to Mr. de Montesquieu" [Translation by the authors. "Il n'est pas une demeure, un champ, une vigne, une touffe d'herbe dans cette région qui n'appartienne pas à Monsieur de Montesquieu"] (Brut-Moncassin, 2006, p.209).
} 
the district of Pujeaux-de-Péougran (6 km south from Bordeaux) because of the higher expected value of the wines (Martin, 1907, p.6; Perceval, 1935, p.30). It was close to one of the most wellknown and wealthy wine producers -Château Haut-Brion. Montesquieu acquired the lands in Pessac for an amount of 60 livres (currency of France until 1795). As he wrote, his intention was to transform it into a land that would be worth 500,000 livres, thereby increasing its value by around 8,000 times (Montesquieu, 1726, p.271). A huge expected gain, provided the land was planted with vines. However, with the 1725 prohibition he could not plant vines on the new acquired lands.

Faced with these (costly) restrictions he first sent a letter to his friend, M. Lamoignon de Courson, the previous intendant of Guyenne (1709-1720), Counsellor of State and brother-in-law of Mr. Le Pelletier, the just-appointed French Controlleur Général. Montesquieu explained the issue to him and tasked for "a permission to plant vines" (Brut-Moncassin, 2006, p.226). Montesquieu then wrote his essay to Mr. Le Pelletier, the just-appointed French Controlleur Général, arguing the need to remove the restrictions on economic ground. When his arguments did not lead to a change in policy, Montesquieu changed tactics. Besides being a political philosopher, writer of economic ideas and wine producer, he was also a wealthy and influential noble, involved in the highest juridical organizations in France. At the time, he was président à mortier (magistrate) in the "parlement" (regional court) of Bordeaux (inherited from his uncle Jean-Baptiste de Secondat). These appeal courts were politically influential and only nobles could purchase or inherit these posts (Dast Le Vacher de Boisville, 1896; Richter, 1977).

While it remains unclear how ("on se sait comment"), Montesquieu ultimately obtained the permission to plant his vines. In fact, Mr. Boucher, the intendant of Guyenne, reported himself 
that "the prohibitions were overridden on all sides, and Montesquieu himself planted his vineyard". 76

Based on these plantings, Montesquieu became a successful wine producer and merchant, ${ }^{77}$ with his wines exported to England (Lacouture, 2003). In many of Montesquieu's letters, reference is made to the 'purity' of his wine,${ }^{78}$ to the exports to England (his main market) ${ }^{79}$ and its increased reputation. ${ }^{80}$ His wine was found "extrêmement bon"-extremely good (Vian, 1879, p.161).

The wine trade, and his success in overcoming the planting rights restrictions, allowed him to travel and to spend time thinking, discussing and ultimately writing up his ideas which influenced much of the Western world. In 1726, he sold his magistrate office and he leased his wine properties in order to have a comfortable rent. He then spent over a year in Paris before travelling to Europe, mainly to England (Richter, 1977, p.14; Walckenaër, 1835, p.xi). After Montesquieu visited many European countries, he returned to France in 1732 and retired to his Castle at La Brède that he considered to be "the most beautiful country retreat that I know of anywhere" (Montesquieu, 1777). After two years he published the book "Considérations sur les causes de la grandeur des Romains et de leur décadence" (Considerations on the Causes of the

\footnotetext{
${ }^{76}$ Translation by the authors. "De fait, on passait outre aux interdictions, de toutes parts, et Montesquieu lui-même planta sa vigne" (Montesquieu, 1726, p.264).

${ }^{77}$ Montesquieu never used merchants as intermediaries; he cultivated his commercial relationships with the influential high society in England (as Lord Elibank) and in France (as the president of the Parlement of Paris, Mr. Marie-Jean Hérault de Séchelles), believing that "I have always had the principle of never having another do what I could do by myself" [Translation by the auhors. "J'ai eu pour principe de ne jamais faire par autrui ce que je pouvais par moimême"] (Montesquieu, 1720/1835, p.620).

78 "I have sent the pipe of wine to Lord Elibank (...). Pray let him know, that he may keep it as long as he pleases (...) but it must not be mixed with any other wines. He may be assured that he has it in the same state of purity in which I received it from the deity. It has not passed through the adulterating hands of wine-merchants." Letter to Abbé de Guasco, June 27, 1752 (In: Montesquieu, 1777).

79 "You must know, my dear Abbé, that I have received very large commissions from England, for the wine of this year (...)." Letter to Abbé de Guasco, June 27, 1752 (In: Montesquieu, 1777).

80 "It is to my friends, but especially to you, who are at any time worth ten others, that I owe the spreading reputation which my wine has acquired through Europe for these three or four years past." Letter to Abbé de Guasco, November 3, 1754 (In: Montesquieu, 1777).
} 
Grandeur and Decadence of the Romans) and, after 16 years, in 1748, he published his famous “De l'Esprit des Lois” (Walckenaër, 1835, p.xiii-xiv).

Hence, ultimately for Montesquieu, political philosophy, excellent wine and (imperfect enforcement of) planting rights reinforced each other. Montesquieu was so successful in the wine trade that he claimed that his wine was more popular in England than his book ("De l'Esprit des Lois"): "my wine becomes more and more in vogue amongst the English, much more so than even my book." 81

\footnotetext{
${ }^{81}$ Nowadays, many of his estates became highly-prized and renowned wines. The Castle at La Brède is nowadays owned by Dominique Haverlan and produces wine sold as AOC Graves under Montesquieu's quote "I am busy here producing nectar" [Translation by the authors: "Je suis occupé ici à faire du nectar"]. Another Montesquieu's vineyard, the Castle Rochemorin, the dependency of the Castle at La Brède, is owned by André Lurton and sold as Pessac-Léognan appellation wines (Coates, 2004; Parker, 2013).
} 


\section{References}

AGRA FACTS. 2013. "Vine Planting Rights - Done," AGRA FACTS No41-13e, News for agribusiness executives. Rose O’Donovan \& Edward Bray (Ed.), Brussels.

Anderson, K., Rausser, G., and Swinnen, J. (2013). Political Economy of Public Policies: Insights from Distortions to Agricultural and Food Markets. Journal of Economic Literature, 51(2), 423-477.

Augé-Laribé, M. (1950). La politique agricole de la France de 1880 à 1940. Paris: Presses Universitaires de France.

Bartoli, P., Boulet, D., Lacombe, P., Laporte, J.-P., Lifran, R. and Montaigne, E. (1987). L'Économie viticole française. Paris: Institut National de la Recherche Agronomique Paris.

Brink, J. E. (1986). Provincial Assemblies and Parlement in Early Modern France: A Review of Historical Scholarship. Legislative Studies Quarterly, 11(3), 429-453.

Brut-Moncassin, M. (2006). Montesquieu, ces dames et le vin. Bègles: Au fil des pages.

CEEV - Comité Européen des Entreprises Vins. (2014). “Open letter on the future vine planting rules in Europe," Comité Européen des Entreprises Vins. Available at «http://www.ceev.eu/news-events-press-releases/press-releases/item/217-wine-plantingsthe-european-wineries-urge-the-ms-to-scale-up-the-ambitions-for-the-development-ofvineyards-in-europe».

Coates, C. (2004). The Wines of Bordeaux: Vintages and Tasting Notes, 1952-2003. California: University of California Press.

Code Rural. (2008). Partie réglementaire, Livre VI: Production et marchés, Titre VI: Les productions végétales, Chapitre V: Gestion du potentiel de production viticole. Available at «http://www.legifrance.com/affichCodeArticle.do;jsessionid=DC6CBDE6853F0332307 1AFAB72062CFD.tpdila11v_3?idArticle=LEGIARTI000019501379\&cidTexte=LEGITE XT000006071367\&dateTexte $=20090718 »$.

Commission Regulation (EEC) No 3800/81 of 16 December 1981 determining the classification of vine varieties. Official Journal of the European Communities. OJ L 381, 31.12.1981, p. $1-78$.

Commission Delegated Regulation (EU) 2015/560 of 15 December 2014 supplementing Regulation (EU) No 1308/2013 of the European Parliament and of the Council as regards the scheme of authorizations for vine plantings. Official Journal of the European Union. OJ L 93/1, 9.4.2015.

Commission Implementing Regulation (EU) 2015/561 of 7 April 2015 laying down rules for the application of Regulation (EU) No 1308/2013 of the European Parliament and of the Council as regards the scheme of authorizations for vine plantings. Official Journal of the European Union. OJ L 93/12, 9.4.2015.

Corsentino, G. (2012). "L'europa scopre 24 mila ettari di vigneti abusivi," Tre Bicchieri Gambero Rosso, October 10. Available at «http://www.gamberorosso.it/ images/quotidianovino/10_ottobre.pdf». 
Council of the European Union. (2014). The voting system at the Council of the EU. Council of the European Union. Available at «http://www.consilium.europa.eu/council/voting-systemat-the-council?tab=In-detail\&subTab=Qualified-majority\&lang=en».

Council Regulation (EEC) No. 24/1962 of 20 April 1962 on the progressive establishment of a common organization of the market in wine. Official Journal of the European Communities.

Council Regulation (EEC) No. 816/70 of 28 April 1970 laying down additional provisions for the common organization of the market in wine. Official Journal of the European Communities.

Council Regulation (EEC) No. 817/70 of 28 April 1970 laying down special provisions relating to quality wines produced in specific regions. Official Journal of the European Communities.

Council Regulation (EEC) No. 1388/70 of 13 July 1970 on general rules for the classification of vine varieties. Official Journal of the European Communities.

Council Regulation (EEC) No 1160/76 of 17 May 1976 amending Regulation (EEC) No 816/70 laying down additional provisions for the common organization of the market in wine. Official Journal of the European Communities.

Council Regulation (EEC) No. 1162/76 of 17 May 1976 on measures designed to adjust winegrowing potential to market requirements. Official Journal of the European Communities.

Council Regulation (EEC) No 1208/84 of 27 April 1984 amending Regulation (EEC) No 337/79 on the common organization of the market in wine. Official Journal of the European Communities.

Crombez, C., Knops, L. and Swinnen, J. (2012). Reform of the Common Agricultural Policy under the Co-decision procedure. Intereconomics, 47(6), 336-42.

Dast Le Vacher de Boisville. (1896). Liste générale et alphabétique des membres du parlement de Bordeaux (1462-1790). Archives historiques de la Gironde. Available at «http://archives.gironde.fr/actu/fiche.asp?id_actu=60».

de Tocqueville, A. (1856). The Old Regime and the Revolution. New York: Harper \& Brothers. Available at «http://oll.libertyfund.org/titles/2419».

Deconinck, K. and Swinnen, J. (2015). The Economics of Planting Rights in Wine Production. European Review of Agricultural Economics, 42(3), 419-440.

Denis, D. (1995). Les plantations de vignes, Montesquieu et l'Administration. Revue de Droit Rural, 235(Août-sept), 386-392.

Devletoglou, N.E. (1963). Montesquieu and the Wealth of Nations. The Canadian Journal of Economics and Political Science, 29(1), 1-25.

Dion, R. (1952). Querelle des anciens et des modernes sur les facteurs de la qualité du vin. Annales de Géographie, 61(328), 417-431.

Dion, R. (1959). Histoire de la vigne et du vin en France des origines au XIXe siècle. CNRS Editions, Paris (mars 2010). 
Durbiano, C. (1975). I.V.C.C., Le vignoble français d'après le cadastre viticole, évolution de 1958 à 1968. Méditerranée, 23(4), 93-94.

EFOW. (2012). Planting rights: Commissioner Ciolos set up a high level group. European Federation of Origin Wines (EFOW), March 22. Available at «www.efow.eu/press/ planting-rights-commissioner-ciolos-set-up-a-high-level-grou_id_124/».

Enjalbert, H. (1953). Comment naissent les grands crus: Bordeaux, Porto, Cognac. Annales, Economies, Sociétés, Civilisations, 8(3), 315-28.

European Commission. (2012). "The EU system of Planting Rights: main rules and effectiveness," Directorate General of Agriculture and Rural Development. Directorate CEconomics of agricultural markets and single CMO. Available at «http://ec.europa.eu/agriculture/wine/high-level-group/index_en.htm».

Franck, W. (1845). Traité sur les vins du Médoc et les autres vins rouges et blancs du département de la Gironde. Bordeaux: Chaumas. Available at «http://gallica.bnf.fr/ark:/12148/bpt6k6529165f».

Fremont-Barnes, G. and Fisher, T. (2004). The Napoleonic Wars: The Rise And Fall Of An Empire. Oxford, UK: Osprey Publishing.

Gaeta, D. and Corsinovi, P. (2014). Economics, Governance, and Politics in the Wine Market: European Union Developments. NY: Palgrave Macmillan.

“Guyenne." (2014). In Encyclopædia Britannica. Retrieved from http://www.britannica.com/ EBchecked/topic/250071/Guyenne.

High Level Group. (2012). "Report of the High Level Group on Wine Planting Rights. FINAL," Available at «http://ec.europa.eu/agriculture/wine/high-level-group/docs/finalreport_en. pdf».

Houdecek, F. (2012). La Grande Armée de 1812: Organization à l'entrée en campagne. In Napoléon Bonaparte, Correspondance générale, Tome XII: La campagne de Russie, 1812. Paris: Fondation Napoléon.

Humbert, F. (2011). "L'INAO, de ses origines à la fin des années 1960: genèse et évolutions du système des vins d'AOC," History. Université de Bourgogne, France. Available at «https://tel.archives-ouvertes.fr/tel-01020855».

INAO. (1943). "Loi du 16 novembre 1942 modifiant le statut viticole," in Bulletin du Comité National des Appellations d'Origine Bulletin de l'Institut National des Appellations d'Origine. Bulletin $\mathrm{n}^{\circ} 17$ juillet 1943, pp. 35-39.

Insee. (1935). Annuaire statistique de la France. Résumé rétrospectif. Institut National de la Statistique et des Etudes Economiques, Paris.

Insee. (1966). Annuaire statistique de la France. Résumé rétrospectif. Institut National de la Statistique et des Etudes Economiques, Paris.

"Intendant." (2014). In Encyclopædia Britannica. Retrieved from http://www.britannica.com /EBchecked/topic/289848/intendant.

Johnson, H. (1989). Vintage: The Story of Wine. New York: Simon and Schuster. 
JORF. (1931, July 5). Loi du 4 juillet 1931 sur La Viticulture et le Commerce des Vins. Journal Officiel de la République Française, p. 7282.

JORF. (1933, July 13). Loi du 8 juillet 1933 sur la Viticulture et le Commerce des Vins. Journal Officiel de la République Française, p. 7310.

JORF. (1934, December 25). Loi du 24 décembre 1934 tendant à réaliser l'Assainissement du Marché des Vins. Journal Officiel de la République Française, p. 12699.

JORF. (1935, July 31). Décret-loi du 30 juillet 1935 Défense du marché des vins et régime économique de l'alcool. Journal Officiel de la République Française, p. 8314.

JORF. (1953, October 1). Décret n53-977 du 30 septembre 1953 relatif à l'organization et l'assainissement du marché du vin et à l'orientation de la production viticole, Journal Officiel de la République Française, p. 8640.

JORF. (1964a). Décret n64-453 du 26 mai 1964 relatif à l'organization du vignoble et à l'amélioration de la qualité de la production viticole, Journal Officiel de la République Française.

JORF. (1964b, September 1). Décret n64-902 du 31 août 1964 relatif à la production viticole et à l'organization du marché du vin, Journal Officiel de la République Française, p. 7951.

JORF. (1972, June 17). Décret nº72-486 du 15 juin 1972 relatif au régime des plantations de vignes, Journal Officiel de la République Française, p. 6142.

JORF. (2015, August 14). Arrêté du 11 août 2015 relatif aux contingents d'autorisations de plantation en vue de produire des vins ne bénéficiant pas d'une appellation d'origine protégée ou d'une indication géographique protégée pour l'année 2015, p. 14109.

Knops, L. and Swinnen, J. (2014). The First CAP Reform under the Ordinary Legislative Procedure: A Political Economy Perspective. Brussels: European Parliament, DirectorateGeneral for Internal Policies.

Knudsen, A.-C. L. (2009). Farmers on Welfare: The Making of Europe's Common Agricultural Policy. Ithaca, NY: Cornell University Press.

La Mare, N. de. (1719). Traité de la Police, où l'on trouvera l'histoire sur l'établissement, les fonctions et les prérogatives de ses magistrats, toutes les lois et tous les règlements qui la concernent. On y a joint une description historique et topographique de Paris et huit plans gravés qui représentent son ancien état et ses divers accroissements; avec un recueil de tous les statuts et règlements des six corps des marchands. Ed: Michel Brunet, Vol. 3, Paris.

Labrousse, C.-E. (1933). Esquisse du mouvement des prix et des revenus en France au XVIIIe siècle, 2 vols. Paris: Dalloz.

Lachiver, M. (1988). Vins, vignes et vignerons. Histoire du vignoble français. Paris: Fayard.

Lacouture, J. (2003). Montesquieu. Les vendanges de la liberté. Paris: Editions du Seuil.

Lane, J.-E. and Ersson, S.O. (2000) The new institutional politics. Outcomes and consequences. Oxford, UK: Routledge.

Le Roy Ladurie, E. (1960). Climat et récoltes aux XVIIe et XVIIIe siècles. Annales. Économies, Sociétés, Civilisations, 15(3), 434-465. 
Loubère, L.A. (1990). The Wine Revolution in France: The Twentieth Century. Princeton, NJ: Princeton University Press.

Lutz, D. S. (1984). The Relative Influence of European Writers on Late Eighteenth-Century American Political Thought. The American Political Science Review, 78(1), 189-197.

Madison, J. (1788). “Separation of Powers,” Federalist, no. 47, 323-31, January 30, 1788. In Hamilton, Alexander; Madison, James; and Jay, John. The Federalist. Edited by Jacob E. Cooke. Middletown, Conn.: Wesleyan University Press, 1961. Available at «http://presspubs.uchicago.edu/founders/documents/v1ch10s14.html».

Martin, G. (1907). Documents relatifs aux défenses de planter des vignes sans autorisation dans la généralité de Guienne au XVIIIe siècle. Mâcon, France: Protat Frères, Imprimeurs.

Meloni, G. and Swinnen, J. (2013). The Political Economy of European Wine Regulations. Journal of Wine Economics, 8(3), 244-284.

Meloni, G. and Swinnen, J. (2014). The Rise and Fall of the World's Largest Wine Exporter And Its Institutional Legacy. Journal of Wine Economics, 9(1), 3-33.

Meloni, G. and Swinnen, J. (2015). The Political Economy of Planting Rights and Grubbing-Up Policies. Unpublished mimeo.

Milhau, J. (1953). L'avenir de la viticulture française. Revue économique, 4(5), 700-738.

Montaigne, E., A. Coelho, B. Delord and Khefifi, L. (2012). Etude sur les impacts socioéconomiques et territoriaux de la libéralisation des droits de plantations viticoles. Tome1, AREV \& UMR - Moisa Montpellier.

Montesquieu, (baron de). (1720/1835). "Pensées Diverses," in Oeuvres complètes de Montesquieu, Paris: Lefèvre. Available at «http://gallica.bnf.fr/ark:/12148/ bpt6k62674924».

Montesquieu, (baron de). (1726). Mémoire contre l'arrêt du Conseil du 27 février 1725 portant défense de faire des plantations en vignes dans la généralité de Guyenne. In Oeuvres complètes de Montesquieu, Volume 3. André Masson (Ed.), Editions Nagel, 1955, pp. 263271.

Montesquieu, (baron de). (1748a). De l'esprit des lois: ou Du rapport que les loix doivent avoir avec la constitution de chaque gouvernement, les moeurs le climat, la religion, le commerce, $\& c$. ; à quoi l'auteur a ajouté. Des recherches nouvelles sur les loix romaines touchant les successions, sur les loix françoises, \& sur les loix féodales, Volume 1. Genève, Barrillot \& Fils. Available at «http://books.google.fr/books?id= 5nAHAAAAQAAJ\&vq=abuser\&hl=fr\&source=gbs_navlinks_s $\gg$.

Montesquieu, (baron de). (1748b). De l'esprit des lois: ou Du rapport que les loix doivent avoir avec la constitution de chaque gouvernement, les moeurs le climat, la religion, le commerce, $\& c$. ; à quoi l'auteur a ajouté. Des recherches nouvelles sur les loix romaines touchant les successions, sur les loix françoises, \& sur les loix féodales, Volume 2. Genève, Barrillot \& Fils. Available at «http://books.google.fr/books?id= GnEHAAAAQAAJ\&vq=domitien $\& h l=$ fr\&source=gbs_navlinks_s $\gg$.

Montesquieu, (baron de). (1777). The Complete Works of M. de Montesquieu. London: T. Evans, 4 vols. Vol. 4. Available at «http://oll.libertyfund.org/titles/864». 
Niederbacher, A. (1983). Wine in the European Community. Office for Official Publication of the European Communities, Periodical 2/3-1983, Luxembourg.

Nye, J.V.C. (2007). War, Wine, and Taxes: The Political Economy of Anglo-French Trade, 1689-1900. Princeton NJ: Princeton University Press.

Paguierre, M. (1829). Classification et description des vins de Bordeaux et des cépages. Paris : Audot.

Parker, R. M. (2013). Bordeaux: A Consumer's Guide to the World's Finest Wines. New York: Simon and Schuster.

Paul, H.W. (1996). Science, Vine and Wine in Modern France. Cambridge: Cambridge University Press.

Perceval, E. de. (1935). Montesquieu et la Vigne. Bordeaux: Delmas.

Plack, N. (2009). Common Land, Wine and the French Revolution. Rural Society and Economy in Southern France, c. 1789-1820. Ashgate, Farhnam.

Regulation (EU) No. 1308/2013 of the European Parliament and of the Council of 17 December 2013 establishing a common organization of the markets in agricultural products and repealing Council Regulations (EEC) No 922/72, (EEC) No 234/79, (EC) No 1037/2001 and (EC) No 1234/2007. Official Journal of the European Union. OJ L 347/671, 20.12.2013.

Richter, M. (1977). The Political Theory of Montesquieu. Cambridge: Cambridge University Press.

Roberts, A. (2014). Napoleon the Great. UK: Penguin.

Robinson, J., ed., (2006). The Oxford Companion to Wine, 3rd edn. Oxford: Oxford University Press.

Serres, Olivier de. (1600). Le théâtre d'agriculture et mésnage des champs. Paris: I. Metayer. Available at «http://gallica.bnf.fr/ark:/12148/bpt6k52175n».

Smith, A. (1776). An Inquiry into the Nature and Causes of the Wealth of Nations. London: Methuen and Co., Ltd., ed. Edwin Cannan, 1904. Fifth edition. Available at «http://www.econlib.org/library/Smith/smWN.html».

Société de législation comparée. (1932). Annuaire de législation française. Publié par la Société de législation comparée, contenant le texte des principales lois votées en France en 1931. Paris: A. Cotillon. Available at http://gallica.bnf.fr/ark:/12148/bpt6k5446891h. image.langFR/.

Spahni, P. (1988). The Common Wine Policy and Price Stabilization. Aldershot, UK: Avebury.

Swinnen, J. (1994). A Positive Theory of Agricultural Protection. American Journal of Agricultural Economics, 76, 1-14.

Swinnen, J. (2011). The Right Price of Food. Development Policy Review, 29(6), 667-688.

Swinnen, J. (2014). "Political economy of EU agricultural and food policies," in Naylor, R. L. (ed.), The Evolving Sphere of Food Security, Oxford: Oxford University Press, pp. 122152. 
Unwin, T. (1991). Wine and the Vine: An Historical Geography of Viticulture and the Wine Trade. Routledge: London and New York.

Vian, L. (1879). Histoire de Montesquieu d'après des documents nouveaux et inédits (2e édition revue et augmentée, précédée d'une préface de M. Éd. Laboulaye). Paris: Didier. Available at «http://gallica.bnf.fr/ark:/12148/bpt6k6457231z».

Vergil. Bucolics, Aeneid, and Georgics Of Vergil. J. B. Greenough. Boston: Ginn \& Co. 1900. Available at «http://www.perseus.tufts.edu/hopper/text?doc=Perseus:text:1999.02.0059».

Walckenaër, C.-A.. (1835). "Notice sur la vie de Montesquieu," in Oeuvres complètes de Montesquieu, Paris: Lefèvre. Available at «http://gallica.bnf.fr/ark:/12148/ bpt6k62674924».

Warner, C.K. (1960). The Winegrowers of France and the Government Since 1875. New York: Columbia University Press. 
Table 1

Chronology of Plantings Restrictions in France and the EU, 1725-2030

\begin{tabular}{|c|c|c|}
\hline Time & Decision-making institutions & Decision/proposal \\
\hline 1725 & King Louis XV & $\begin{array}{l}\text { Prohibition to plant vines in the Bordeaux } \\
\text { wine region }\end{array}$ \\
\hline 1731 & King Louis XV & $\begin{array}{l}\text { - Prohibition to plant vines was extended to } \\
\text { the entire French kingdom }\end{array}$ \\
\hline 1789 & National Constituent Assembly & $\begin{array}{l}\text { - Abolished privileges and the feudal regime } \\
\text { "Freedom of planting" }\end{array}$ \\
\hline $1931-35$ & French government & $\begin{array}{l}\text { - The Statut Viticole introduced planting } \\
\text { rights regime }\end{array}$ \\
\hline WWII & $\begin{array}{l}\text { French government } \\
\text { ("Vichy regime") }\end{array}$ & $\begin{array}{l}\text { - The Statut Viticole was suspended } \\
\text { "Freedom of planting" }\end{array}$ \\
\hline 1953 & French government & $\begin{array}{l}\text { - Code du Vin (re-)introduced planting rights } \\
\text { regime }\end{array}$ \\
\hline 1964 & French government & $\begin{array}{l}\text { - The } 1964 \text { law eased rules on market } \\
\text { intervention and on planting rights }\end{array}$ \\
\hline 1970 & $\begin{array}{l}\text { European Economic Community } \\
(\text { EEC) }\end{array}$ & $\begin{array}{l}\text { - Regulations introduced restrictions on the } \\
\text { replanting of vines for EEC }\end{array}$ \\
\hline 1976 & $\begin{array}{l}\text { European Economic Community } \\
(E E C)\end{array}$ & $\begin{array}{l}\text { - Complete ban on all new plantings for table } \\
\text { wines }\end{array}$ \\
\hline 1984 & $\begin{array}{l}\text { European Economic Community } \\
(E E C)\end{array}$ & $\begin{array}{l}\text { - Regulations introduced restrictions on } \\
\text { planting rights for "high quality" wines }\end{array}$ \\
\hline 2006 & European Union (EU) & $\begin{array}{l}\text { - The European Commission proposes to } \\
\text { liberalize the planting rights regime }\end{array}$ \\
\hline 2008 & European Union (EU) & $\begin{array}{l}\text { - EU Ministers of Agriculture adopted the } \\
\text { EU Commission's proposal to liberalize the } \\
\text { planting rights by } 2016 / 2018\end{array}$ \\
\hline 2013 & European Union (EU) & $\begin{array}{l}\text { - The earlier agreed liberalization of the } \\
\text { planting right system was overturned } \\
\text { - Decision to extend the planting restrictions } \\
\text { until } 2030\end{array}$ \\
\hline 2016 & European Union (EU) & $\begin{array}{l}\text { - A new program of "authorizations" for new } \\
\text { plantings starting in } 2016 \text { and ending in } \\
2030\end{array}$ \\
\hline
\end{tabular}


Table 2

Plantings Restrictions in France and in Italy, 1950s-1970s

\begin{tabular}{|c|c|c|c|c|}
\hline \multirow[t]{2}{*}{ Time } & \multicolumn{2}{|c|}{ France } & \multicolumn{2}{|c|}{ Italy } \\
\hline & High quality & Low quality & High quality & Low quality \\
\hline \multirow[t]{3}{*}{1953} & Yes $^{1}$ & Yes & No & No \\
\hline & $\begin{array}{l}\text { - AOC rules } \\
\quad \text { (specific varieties) }\end{array}$ & $\begin{array}{l}\text { - New plantings } \\
\text { not allowed }\end{array}$ & & \\
\hline & $\begin{array}{l}\text { - New plantings } \\
\text { allowed (only for } \\
\text { rec. var.) }\end{array}$ & $\begin{array}{l}\text { - Replanting } \\
\text { allowed for rec. } \\
(100 \%) \text { and auth. } \\
(70 \%) \text { var. }\end{array}$ & & \\
\hline \multirow[t]{3}{*}{1964} & Yes & Yes & Yes & No \\
\hline & $\begin{array}{l}\text { - AOC rules } \\
\quad \text { (specific varieties) }\end{array}$ & $\begin{array}{l}\text { - New plantings } \\
\text { allowed (only for } \\
\text { rec. var.) }\end{array}$ & $\begin{array}{l}\text { 1963: DOC rules } \\
\text { (specific varieties) }\end{array}$ & \\
\hline & $\begin{array}{l}\text { - New plantings } \\
\text { allowed (only for } \\
\text { rec. var.) }\end{array}$ & $\begin{array}{l}- \text { Replanting } \\
\text { allowed for rec. } \\
\text { (100\%) and auth. } \\
(70 \%) \text { var. }^{3}\end{array}$ & & \\
\hline \multirow[t]{3}{*}{ 1970 $^{4}$} & Yes & Yes & Yes & Yes \\
\hline & $\begin{array}{l}\text { - AOC rules } \\
\quad \text { (specific varieties) }\end{array}$ & $\begin{array}{l}\text { - New plantings } \\
\text { allowed (for rec. } \\
\text { \& auth. var.) }\end{array}$ & $\begin{array}{l}\text { - DOC rules } \\
\quad \text { (specific varieties) }\end{array}$ & $\begin{array}{l}- \text { New plantings } \\
\text { allowed (for rec. } \\
\text { \& auth. var.) }\end{array}$ \\
\hline & $\begin{array}{l}\text { - New plantings } \\
\text { allowed (only for } \\
\text { rec. var.) }\end{array}$ & $\begin{array}{l}\text { - Replanting } \\
\text { allowed for rec. } \\
\text { (100\%) and auth. } \\
(70 \%) \text { var. }\end{array}$ & $\begin{array}{l}\text { - New plantings } \\
\text { allowed (for rec.\& } \\
\text { auth. var.) }\end{array}$ & $\begin{array}{l}\text { - Replanting } \\
\text { allowed (for } \\
\text { rec.\&auth. var.) }\end{array}$ \\
\hline \multirow[t]{3}{*}{1976} & Yes & Yes & Yes & Yes \\
\hline & $\begin{array}{l}\text { - AOC rules } \\
\quad \text { (specific varieties) }\end{array}$ & $\begin{array}{l}\text { - New plantings } \\
\text { not allowed }\end{array}$ & $\begin{array}{l}\text { - DOC rules } \\
\quad \text { (specific varieties) }\end{array}$ & $\begin{array}{l}\text { - New plantings } \\
\text { not allowed }\end{array}$ \\
\hline & $\begin{array}{l}\text { - New plantings } \\
\text { allowed (only for } \\
\text { rec. var.) }\end{array}$ & $\begin{array}{l}\text { - Replanting } \\
\text { allowed for rec. } \\
\text { (100\%) and auth. } \\
\text { (70\%) var. }\end{array}$ & $\begin{array}{l}\text { - New plantings } \\
\text { allowed (for rec.\& } \\
\text { auth. var.) }\end{array}$ & $\begin{array}{l}\text { - Replanting } \\
\text { allowed (for } \\
\text { rec.\&auth.var.) }\end{array}$ \\
\hline
\end{tabular}

Notes:

${ }^{1}$ Yes/No refers to whether there are planting restrictions.

2 "rec. var." stands for "recommended varieties" and "rec.\& auth. var." for "recommended and authorized varieties".

${ }^{3}$ Restrictions on replanting rights were included in the French Rural Code (see Article R665-16).

${ }^{4}$ From 1970, the Common Wine Policy applied to both countries but more restrictive national regulations could be introduced.

5 "Allowed" means replanting rights for $100 \%$, unless explicitly indicated. 
Table 3

Planting Rights and Authorizations, a Comparison

\begin{tabular}{|c|c|c|}
\hline & Planting Rights & Authorizations \\
\hline Time Frame & Until December 31, 2015 & $\begin{array}{l}\text { From January 1, } 2016 \text { to December } \\
31,2030\end{array}$ \\
\hline Vineyard expansion & No growth possible & $\begin{array}{l}\text { Growth possible: annual maximum } \\
\text { percentage of growth corresponding } \\
\text { to } 1 \% \text { of the member states total area } \\
\text { planted with vines }\end{array}$ \\
\hline Mode of delivery & $\begin{array}{l}\text { Issued on the basis of } \\
\text { national and regional } \\
\text { priorities }\end{array}$ & $\begin{array}{l}\text { - Issued automatically if the } \\
\text { number of available } \\
\text { authorizations is higher than the } \\
\text { total demand. } \\
\text { - Otherwise, issued proportionally } \\
\text { or through a priority criteria }\end{array}$ \\
\hline Period of validity & $\begin{array}{l}8 \text { years for replanting rights; } \\
2 \text { years for rights issued from } \\
\text { reserves }\end{array}$ & 3 years \\
\hline Acquisition & Not freely granted & Freely granted \\
\hline $\begin{array}{l}\text { Tradability of the } \\
\text { rights }\end{array}$ & Possible & Impossible \\
\hline Wine segments & PDO and PGI wines & PDO, PGI and wines without a GI \\
\hline
\end{tabular}


Figure 1

The French 1953 Classification of Vine Varieties and the "Quality" Pyramid

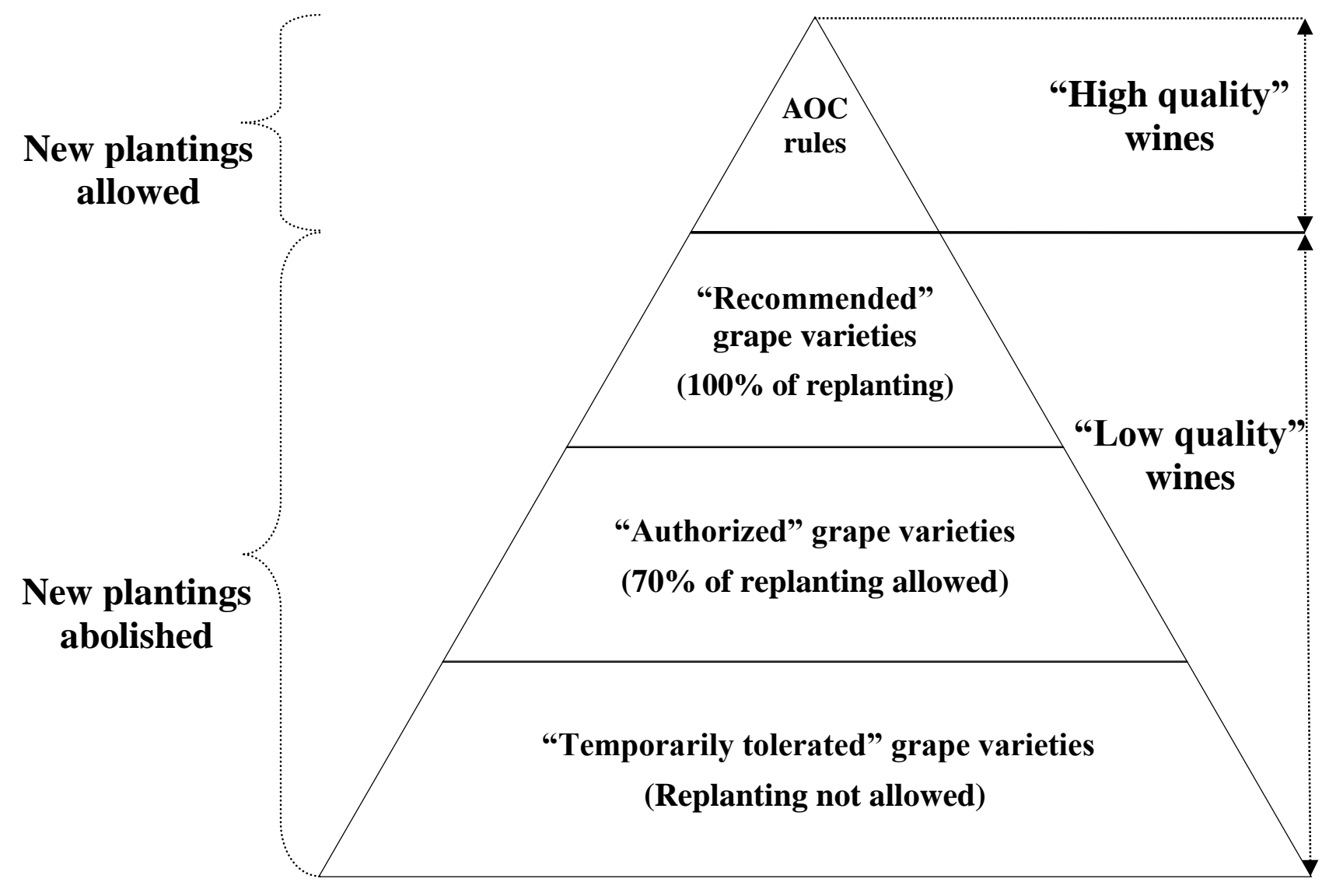

Source: Author's calculations. 